Universidade de São Paulo

Escola Superior de Agricultura "Luiz de Queiroz"

Aferição do teste de germinação das sementes de milho em função do tratamento industrial das sementes

Aline Neves Martins

Dissertação apresentada para obtenção do título de Mestra em Ciências. Área de concentração: Fitotecnia

Piracicaba

2017 
Aline Neves Martins

Engenheira Agrônoma

Aferição do teste de germinação das sementes de milho em função do tratamento industrial das sementes

Orientadora:

Profa. Dra. ANA DIONISIA DA LUZ COELHO NOVEMBRE

Dissertação apresentada para obtenção do título de Mestra em Ciências. Área de concentração: Fitotecnia.

Piracicaba 

Dados Internacionais de Catalogação na Publicação
DIVISÃO DE BIBLIOTECA - DIBD/ESALQ/USP

Martins, Aline Neves

Aferição do teste de germinação das sementes de milho em função do tratamento industrial das sementes / Aline Neves Martins. - - Piracicaba, 2017.

$56 \mathrm{p.}$

Dissertação (Mestrado) - - USP / Escola Superior de Agricultura "Luiz de Queiroz".

1. Zea mays 2. Análise de sementes 3. Tratamento de sementes 4. Produtos químicos I. Título 


\section{AGRADECIMENTOS}

A Deus e a minha família.

À Profa. Ana Dionisia da Luz Coelho Novembre, pela orientação e oportunidade de aprendizado profissional e pessoal.

À Helena Maria Carmignani Pescarin Chamma, que apoia todos os alunos sementeiros da ESALQ, por tornar possível a condução das pesquisas.

À Nilceli Fernandes Buzzerio, da Syngenta, por possibilitar o tratamento das sementes.

À Coordenação de Aperfeiçoamento de Pessoal de Nível Superior - CAPES, pela bolsa de estudo.

À Profa. Sônia Maria de Stefano Piedade, pelos conhecimentos compartilhados de Estatística. Aos Professores Paulo Hercílio Viegas Rodrigues, José Otávio Machado Menten, Silvio Moure Cícero, Ricardo Leite Camargo e Marisa Aparecida Bismara Regitano d’Arce.

Aos funcionários Francisco Guilhien Gomes Junior, Maria Heloisa Duarte de Moraes, Luciane Aparecida Lopes Toledo e Luis Claudio Pereira Sousa.

Aos funcionários e amigos do Laboratório de Sementes da ESALQ, pela parceria e pela ajuda. 
SUMÁRIO

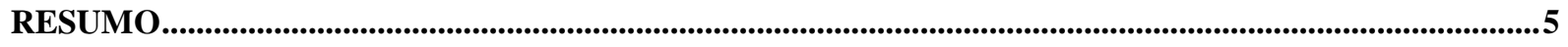

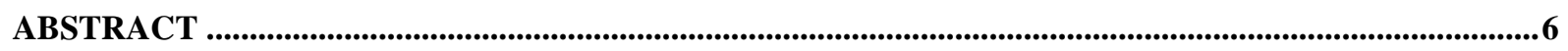

1. INTRODUÇÃO...........................................................................................................................................................

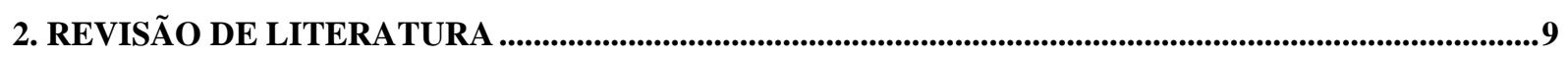

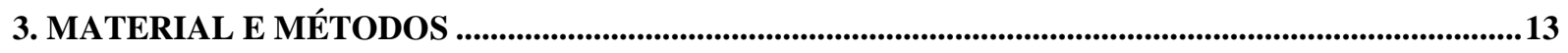

4. RESULTADOS E DISCUSSÃO ..............................................................................................................17

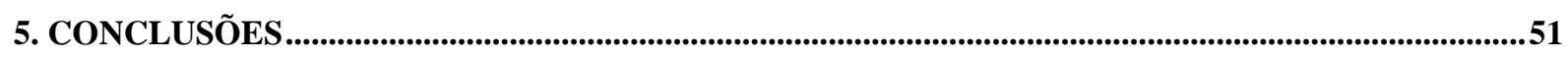

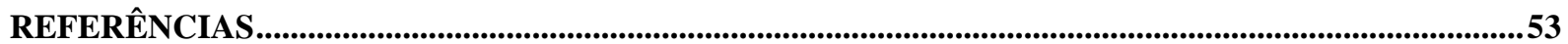


RESUMO

\title{
Aferição do teste de germinação das sementes de milho em função do tratamento industrial das sementes
}

\begin{abstract}
O tratamento industrial de sementes é utilizado para, aproximadamente, 100\% das sementes híbridas de milho comercializadas no Brasil. Assim, é essencial verificar se a aplicação de produtos químicos nas sementes de milho interfere nos resultados das análises destas sementes. Portanto, nesta pesquisa foi comparada a germinação das sementes híbridas de milho de três cultivares classificadas em peneiras de crivo circular e oblongo, em função da aplicação de produtos químicos (fungicida, inseticida, nematicida e polímero) em relação às sementes sem tratamento químico (Controle). Para complementar a determinação da qualidade das sementes foram avaliados o teor de água das sementes, o comprimento médio da raiz da plântula, a emergência da plântula e o vigor. As análises foram realizadas no Departamento de Produção Vegetal da Escola Superior de Agricultura "Luiz de Queiroz", Universidade de São Paulo. O teor de água foi determinado pelo método da estufa a $105 \pm$ $3{ }^{\circ} \mathrm{C}$, por 24 horas. Para o teste de germinação foram utilizados o substrato papel (RP), quatro repetições de 50 sementes ou oito repetições de 25 sementes e as avaliações entre o 3o e o 7o dia após a instalação do teste. Os tratamentos com fungicida, inseticida e nematicida não interferiram no teor de água das sementes de milho, independentemente do genótipo e da forma das sementes. Os resultados do teste de germinação das sementes de milho foram analisados, estatisticamente e utilizando as Tabelas de Tolerância das Regras para Análise de Sementes, e é possível verificar que o tratamento industrial das sementes não interfere nos resultados do teste de germinação, conforme proposto nas atuais Regras para Análise de Sementes. No teste de germinação, é possível avaliar a germinação das sementes de milho no 3o dia após a instalação do teste, para antecipar a obtenção dos resultados. A colocação de 25 sementes de milho no substrato papel (RP) favorece a avaliação do desenvolvimento da plântula no teste de germinação, em comparação à utilização de 50 sementes.
\end{abstract}

Palavras-chave: Zea mays; Análise de sementes; Tratamento de sementes; Produtos químicos 


\section{ABSTRACT \\ Maize seeds germination test depending on the seed industrial treatment}

The seed industrial treatment is used to approximately $100 \%$ of the maize hybrids seeds marketed in Brazil. Thus, it is essential to verify if the application of chemical products in maize seeds interferes in the analysis results of these seeds. Therefore, in this research was compared maize seeds germination of three cultivars classified in circular and oblong screen sieves, depending on the application of chemical products (fungicide, insecticide, nematicide and polymer) in relation to the seeds without chemical treatment (Control). In order to complement the determination of seed quality, seed water content, seedling root mean length, seedling emergence and vigor were evaluated. The analysis were carried out in the Plant Production Department of the Luiz de Queiroz College of Agriculture, University of São Paulo. The water content was determined by the oven method at $105 \pm$ $3{ }^{\circ} \mathrm{C}$ for 24 hours. In the germination test, the paper substrate (RP), four replicates of 50 seeds or eight replicates of 25 seeds were used and the evaluations between the 3rd and the 7 th day after of the test installation. The treatments with fungicide, insecticide and nematicide did not interfere in the water content of the maize seeds, independently of the genotype and the seeds shape. The results of the maize seeds germination test were statistically analyzed and using the Tolerance Tables of the Rules for Seed Testing and it is possible to verify that the seed industrial treatment does not interfere in the results of the germination test, as proposed in the current Rules for Seed Testing. In the germination test, it is possible to evaluate the maize seeds germination on the 3rd day after the test installation, in order to anticipate the results. The placement of 25 maize seeds on the paper substrate (RP) favors the evaluation of the seedling development in the germination test, compared to the use of 50 seeds.

Keywords: Zea mays; Seed analysis; Seed treatment; Chemical products 


\section{INTRODUÇÃO}

O teste de germinação tem o objetivo de aferir a qualidade de um lote de sementes e viabilizar a emissão de documentos para a comercialização. As Regras para Análise de Sementes - RAS (BRASIL, 2009) têm a finalidade de disponibilizar métodos oficiais e padronizados para Análise de Sementes, os quais são obrigatórios para a produção e o comércio de sementes em função da Lei de Sementes.

As amostras de sementes tratadas quimicamente devem ser identificadas com o nome do produto, do ingrediente ativo e dosagem utilizada (BRASIL, 2009). Entretanto, os procedimentos das RAS foram estabelecidos para as sementes não tratadas e, portanto, os resultados devem ser aferidos para a análise de sementes tratadas. Assim, é importante verificar por meio de testes com sementes tratadas se diferentes tratamentos químicos interferem nos resultados das análises e se há necessidade de modificar ou adequar os métodos propostos.

O milho é uma das principais espécies em quantidade de produção de sementes e área plantada de grãos no Brasil, aproximadamente 370 mil toneladas e 15,7 milhões de hectares na safra 2014/2015 (ABRASEM, 2015). Devido a essa importância, o milho é uma espécie de interesse para a verificação dos procedimentos de análise de sementes tratadas em comparação com as sementes sem tratamento químico.

Para verificar se há interferência dos produtos fitossanitários nos resultados da análise das sementes de milho, este trabalho teve o objetivo de comparar a germinação de sementes de milho tratadas em relação às sementes sem tratamento químico (Controle). Foram utilizadas sementes híbridas de milho de três cultivares classificadas em peneiras de crivo circular e oblongo (sementes redondas e chatas, respectivamente). Para o tratamento das sementes foram aplicados fungicida, inseticida, nematicida e polímero. Os resultados do teste de germinação foram obtidos nas condições de temperatura e umidade dos métodos propostos pelas RAS, em diferentes momentos de avaliação (do terceiro ao sétimo dia após a semeadura). Também foram analisados comprimento médio da raiz, emergência da plântula e teste de frio. 


\section{REVISÃO DE LITERATURA}

Os principais produtores mundiais de milho são os Estados Unidos, o Brasil e a China, que representam 36, 23 e 7\% da produção na safra 2015/2016 (USDA, 2016). No Brasil o milho representa, aproximadamente, 36\% da produção de grãos (CONAB, 2016). De acordo com a Associação Brasileira das Indústrias de Milho - ABIMILHO, na safra 2015/2016, cerca de 57\% da demanda de milho no Brasil foi para o consumo animal, $8 \%$ para a indústria e 2\% para a alimentação humana (ABIMILHO, 2016). Os cinco principais Estados produtores de milho para grão no Brasil são: Mato Grosso (24\%), Paraná (22\%), Mato Grosso do Sul (10\%), Minas Gerais (9\%) e Goiás (8\%), segundo dados do IBGE (2016).

A demanda de sementes para a cultura do milho varia entre as regiões, dependendo do nível tecnológico da produção. As sementes de milho correspondem a 37\% de um total de aproximadamente $\mathrm{R} \$ 10$ bilhões do mercado de sementes no Brasil e a taxa média de utilização de sementes de milho no Brasil é de 90\% (ABRASEM, 2015). No Registro Nacional de Cultivares (RNC) estão cadastrados os cultivares habilitados para a produção, comercialização e utilização de sementes em todo território nacional. Para o milho há aproximadamente 2.700 híbridos registrados e $43 \%$ desses genótipos são geneticamente modificados (ABRASEM, 2015). Para a safra de 2016/2017, as sementes corresponderam a valores médios de $30 \%$ dos custos com insumos e $15 \%$ do custo total da produção no Estado do Mato Grosso, principal produtor nacional (IMEA, 2016).

No Brasil, aproximadamente $100 \%$ das sementes híbridas de milho são tratadas na indústria com fungicidas, $35 \%$ com inseticidas e o restante recebe a aplicação de inseticida na propriedade agrícola (NUNES, 2016).

Os produtos fitossanitários são utilizados há mais de 100 anos no Brasil (MENTEN et al., 2005), porém o avanço no tratamento de sementes ocorreu a partir década de 70, quando foi introduzido o tratamento na indústria, inicialmente em sementes de milho (NUNES, 2016). Atualmente, existem 78 produtos comerciais registrados para o tratamento de sementes e quatro produtos registrados para "tratamento de sementes/aplicação foliar". Os ingredientes ativos registrados para o tratamento de sementes de milho são fungicida, inseticida, nematicida, protetor de sementes e regulador de crescimento. Para a planta do milho há 53 produtos registrados para tratamento de sementes e dois produtos registrados para “tratamento de sementes/aplicação foliar" (AGROFIT, 2017).

A evolução do tratamento de sementes no Brasil foi permitida pelo desenvolvimento de tecnologias, como sistemas de atomização, controladores lógicos programáveis, 
computadores, balanças para medir fluxo de sementes, bombas de alta precisão, sistemas de medição de produtos por perda de peso, entre outras, que permitem a aplicação simultânea de até nove produtos diferentes (NUNES, 2016).

O tratamento de sementes tem a finalidade de proteger as sementes e as plântulas de patógenos e impedir o início de uma epidemia (DHINGRA et al., 1980). Os patógenos controlados com o tratamento de sementes são aqueles associados às sementes, habitantes do solo, fungos de armazenamento e patógenos foliares da fase de início de desenvolvimento da planta. O tratamento sanitário de sementes é classificado como químico - quando é aplicado produto químico, físico - através do calor (termoterapia), biológico - pelo uso de agentes de biocontrole, ou bioquímico - via fermentação anaeróbica (MENTEN; MORAES, 2010). Além do tratamento protetor ou sanitário para o controle de doenças e de pragas, o conceito atual de tratamento de sementes abrange os produtos ou processos que não têm propriedades biocidas como os polímeros, corantes, hormônios, micronutrientes, Rhizobium ou condicionamento osmótico, denominados de tratamentos funcionais (MACHADO et al., 2006).

A prática do tratamento de sementes na propriedade agrícola é de fácil utilização e baixo custo, entretanto, alguns produtos não são adequadamente distribuídos em todas as sementes tratadas (FANCELLI; DOURADO NETO, 2004). Apesar desse fator não ser limitante para o tratamento de sementes, esse risco de variação na quantidade e na cobertura dos produtos aplicados nas sementes é maior quando o tratamento ocorre nas propriedades agrícolas sem equipamentos especiais. A fim de melhorar a adesão dos produtos, reduzir a formação de pó durante o tratamento de sementes e, consequentemente, reduzir o risco de intoxicações, são adicionados polímeros no tratamento industrial de sementes, que também favorecem a plantabilidade e reduzem o número de falhas do estande de plantas (CRUZ et al., 2015). Os polímeros são compostos de origem natural ou sintética formados por um grande número de moléculas repetidas (AKCELRUD, 2007). Antes da aplicação dos produtos para o tratamento de sementes, é necessário identificar os patógenos e as pragas que afetam a cultura, para a escolha adequada de tratamentos fungicidas, inseticidas e nematicidas registrados, de acordo com o espectro de ação ou especificidade dos ingredientes ativos (PARISI; MEDINA, 2013).

Os principais ingredientes ativos utilizados para o tratamento de sementes no Brasil são os inseticidas fipronil, tiametoxam, imidacloprido, clotianidina, tiodicarbe e os fungicidas fludioxonil e tiofanato-metílico (NUNES, 2016; AGROFIT, 2017). A abamectina é um 
importante nematicida utilizado para o tratamento de sementes (ARAÚJO, 2016) e também é classificada como inseticida (IRAC, 2016).

Nas sementes são aplicadas diferentes combinações de produtos químicos. O fungicida sistêmico composto pela combinação de fludioxonil, metalaxil-M e tiabendazol (grupo químico, fenilpirrol, acilalaninato, benzimidazol, respectivamente), o inseticida tiametoxam e o nematicida abamectina estão entre os ingredientes ativos registrados para a planta do milho (AGROFIT, 2017).

A formulação fludioxonil, metalaxil-M e tiabendazol é indicada para o milho no controle de Fusarium moniliforme, Penicillium digitatum, Aspergillus flavus (AGROFIT, 2017). Espécies do gênero Fusarium causam podridão do colmo e das espigas do milho. Aspergillus spp. e Penicillium sp. são fungos que causam podridão nas sementes armazenadas (COSTA et al., 2009). O grupo químico fenilpirrol atua na transdução de sinal, o acilalaninato na síntese de ácidos nucleicos e o benzimidazol na mitose e divisão celular dos fungos (FRAC, 2016).

A abamectina é indicada para o controle dos nematoides Pratylenchus brachyurus e Pratylenchus zeae (AGROFIT, 2017), que causam danos para a planta do milho no Brasil, devido à patogenicidade, à distribuição e à alta densidade populacional. Os nematoides prejudicam o sistema radicular interferindo na absorção de água e nutrientes, reduzindo o desenvolvimento e a produção da planta do milho. Os sintomas causados por Pratylenchus spp. são lesões radiculares e apodrecimento de raízes (COSTA et. al, 2009)

Tiametoxam é um inseticida sistêmico, de alta solubilidade em água, eficiente para o controle de insetos sugadores (GAZZONI, 2008) é do grupo químico dos neonicotinoides, que atua sobre o sistema nervoso ou musculatura dos insetos (IRAC, 2016). Para a cultura do milho, tiametoxam é indicado no controle de coró, percevejo barriga verde, lagarta-elasmo, cigarrinha-das-pastagens e cigarrinha-do-milho (AGROFIT, 2017), que podem afetar o desenvolvimento das plantas e reduzir a produção (CRUZ, 2008).

O tratamento de sementes é uma das medidas utilizadas no manejo de pragas. Os inseticidas sistêmicos aplicados no tratamento protegem as sementes e as plântulas pelo efeito de repelência ou causando a morte dos insetos. O custo com inseticidas é menor quando são aplicados nas sementes ao invés da aplicação no sulco de plantio ou por pulverização, em função da redução da quantidade de produto químico. As aplicações complementares de inseticidas variam com a praga e o nível de infestação (CRUZ, 2008).

Quando o tratamento de sementes é realizado na indústria, além da eficiência do tratamento e segurança da equipe de trabalho, são realizados testes para verificar possíveis 
alterações na germinação e no vigor (NUNES, 2016). Portanto, as amostras de sementes tratadas são comuns nos laboratórios de análise de sementes. Entretanto, as legislações em vigência no Brasil e os procedimentos de análise de sementes foram estabelecidos baseados em testes com sementes não tratadas (MENTEN, 2016).

Villela et al. (2013) avaliaram sementes de milho em diferentes combinações de substratos (papel Germitest e papel pardo com vermiculita, carvão ou sementes préhidratadas), duas quantidades de sementes ( 25 ou 50) e duas temperaturas ( 25 ou $30^{\circ} \mathrm{C}$ ) para o teste de germinação. Os autores concluíram que, para os híbridos de milho tolerantes ao tratamento químico, não há necessidade de alteração dos métodos oficiais. Para os híbridos de milho suscetíveis, os autores concluíram que o teste de germinação deve incluir vermiculita junto ao papel, a $25^{\circ} \mathrm{C}$.

As avaliações da germinação de sementes de milho são feitas no $4^{0}$ e no $7^{0}$ dia após a semeadura, conforme as indicações das RAS (BRASIL, 2009). Estes momentos de avaliação precisam ser aferidos para verificar se há variação dos resultados da germinação em função do tratamento industrial das sementes.

A forma das sementes também é outro fator que pode interferir nos resultados do teste de germinação de sementes tratadas e não tratadas. Aguilera et al. (2000) verificaram que as sementes de milho chatas e tratadas tem germinação estatisticamente superior às sementes redondas e não tratadas. Bulegon et al. (2015) observaram que o tipo de tratamento químico e a forma das sementes híbridas de milho podem interferir no resultado do teste de germinação. 


\section{MATERIAL E MÉTODOS}

As análises foram realizadas no Departamento de Produção Vegetal da Escola Superior de Agricultura "Luiz de Queiroz", Universidade de São Paulo. Foram utilizadas sementes híbridas comerciais de milho de três cultivares, classificadas como redondas (H1R, H2R, H3R) e chatas (H1C, H2C, H3C) em peneiras de crivo circular e oblongo, respectivamente. Os produtos foram aplicados nas sementes utilizando equipamento de batelada e de forma similar ao utilizado nas empresas que fazem o tratamento industrial de sementes.

Tratamentos: fungicida (fludioxonil + metalaxil-M + tiabendazol) + polímero, fungicida + inseticida (tiametoxam) + polímero e fungicida + inseticida + nematicida (abamectina) + polímero, nas doses recomendadas na bula de cada produto (Tabela 1). Os tratamentos químicos foram comparados com o Controle (sem aplicação de produtos químicos).

Tabela 1. Doses dos produtos aplicadas nas sementes híbridas de milho 1, 2 e 3

\begin{tabular}{cc}
\hline Ingrediente ativo & Dose (ml/60.000 sementes) \\
\hline fludioxonil + metalaxil-M + tiabendazol & 30 \\
tiametoxam & 120 \\
abamectina & 60 \\
\hline
\end{tabular}

Teor de água (TA): foi determinado (em porcentagem de água) pelo método da estufa a $105 \pm 3{ }^{\circ} \mathrm{C}$, por 24 horas, de acordo com as Regras para Análise de Sementes (BRASIL, 2009), com duas repetições por tratamento.

Teste de germinação (TG): as sementes foram colocadas em papel, umedecido com volume de água equivalente a 2,5 vezes a massa do papel seco, com quatro repetições de 50 sementes ou oito repetições de 25 sementes para cada tratamento e para cada dia de avaliação ( $3^{\underline{o}}$ ao $7^{\underline{0}}$ dia após a semeadura). As sementes foram mantidas em germinador a $25^{\circ} \mathrm{C}$, com fotoperíodo de 12 horas. Os resultados são expressos em porcentagem de plântulas normais (BRASIL, 2009). 
Comprimento da raiz (CR): comprimento médio das raízes de 10 plântulas de cada repetição do teste de germinação. Os resultados são expressos em centímetros.

Emergência da plântula (EP): em caixas plásticas $(40$ x 30 x $10 \mathrm{~cm})$ preenchidas com areia lavada de textura média foram semeadas quatro repetições de 50 sementes ou oito repetições de 25 sementes para cada tratamento. O substrato foi umedecido até $60 \%$ da capacidade de retenção da areia e as caixas foram mantidas em condições não controladas de temperatura e umidade relativa do ar. As avaliações foram realizadas a partir do início da emergência da plântula até a estabilização. Os resultados são expressos em porcentagem de plântulas emersas.

Índices de velocidade de germinação (IVG) e de velocidade de emergência da plântula (IVEP): calculados com os dados dos testes de germinação e de emergência da plântula, utilizando a fórmula proposta por Maguire (1962).

Tempo médio de germinação (TMG) e tempo médio de emergência da plântula (TMEP): calculados com os dados dos testes de germinação e de emergência da plântula (em dias), utilizando a fórmula proposta por Edmond e Drapala (1958).

Teste de frio (F): conduzido em caixas plásticas $(40$ x $30 \times 10 \mathrm{~cm})$ preenchidas com substrato formado pela mistura de areia lavada de textura média e terra, na proporção 3:1. Foram utilizadas quatro repetições de 50 sementes para cada tratamento. O substrato foi umedecido com água correspondente a $60 \%$ da sua capacidade de retenção e as caixas foram mantidas em câmara fria a $10{ }^{\circ} \mathrm{C}$ por sete dias. Em seguida, as caixas permaneceram por mais sete dias em condições não controladas de ambiente, com avaliação no sétimo dia. Os resultados são expressos em porcentagem de plântulas emersas.

Análise estatística: os testes foram conduzidos em delineamento experimental inteiramente aleatorizado. Os dados foram analisados no programa Statistical Analysis System (SAS) e as médias foram comparadas pelo teste de Tukey $(\alpha=0,05)$. No teste de germinação foi utilizado o esquema fatorial $5 \times 4$ (cinco momentos de avaliação e quatro tratamentos Controle, fungicida + polímero, fungicida + inseticida + polímero, fungicida + inseticida + nematicida + polímero) e as médias foram comparadas também por meio das Tabelas de 
Tolerâncias das Regras para Análise de Sementes, 18.9 e 18.10 (ISTA, 1963 citado por BRASIL, 2009). 


\section{RESULTADOS E DISCUSSÃO}

Os resultados referentes à determinação do teor de água das sementes de milho H1R, H2R, H3R, H1C, H2C, H3C (Tabela 2) indicaram que a variação entre o maior e o menor resultado para cada híbrido e forma (variação máxima) é inferior a $0,5 \%$, portanto, não houve interferência dos tratamentos no teor de água sementes.

Tabela 2. Teor de água (\%) das sementes híbridas de milho, 1, 2 e 3, classificadas como redondas $(\mathrm{R})$ e chatas $(\mathrm{C})$ em função dos tratamentos

\begin{tabular}{lcccccc}
\hline Tratamento & H1R & H2R & H3R & H1C & H2C & H3C \\
\hline Controle & 7,4 & 8,2 & 7,8 & 8,3 & 7,9 & 7,7 \\
fungicida & 7,8 & 8,0 & 7,4 & 8,3 & 7,6 & 7,4 \\
fungicida + inseticida & 7,7 & 8,3 & 7,6 & 8,3 & 7,8 & 7,4 \\
fungicida + inseticida + & 7,6 & 8,1 & 7,6 & 8,3 & 7,9 & 7,6 \\
nematicida & 0,4 & 0,3 & 0,4 & 0,0 & 0,3 & 0,3 \\
\hline Variação máxima & & & & & & \\
\hline
\end{tabular}

$\mathrm{Na}$ análise de variância, os valores da probabilidade (p) para a interação entre os fatores tratamento e momento de avaliação para o teste de germinação das repetições de 50 sementes são maiores que 0,05 (Tabela 3), ou seja, a interação não é significativa $(\alpha=0,05)$.

Tabela 3. Probabilidade (p) da interação entre os fatores momento de avaliação e tratamento para o teste de germinação das sementes de milho das repetições de 50 sementes

\begin{tabular}{cccccc}
\hline H1R & H2R & H3R & H1C & H2C & H3C \\
\hline 0,7844 & 0,1417 & 0,8393 & 0,0948 & 0,2820 & 0,0991 \\
\hline
\end{tabular}

Portanto, os fatores analisados são independentes e não interferem nos resultados da análise (Tabela 4). 
Tabela 4. Germinação de sementes de milho (\%) por tratamento e momento de avaliação nas repetições de 50 sementes

\begin{tabular}{|c|c|c|c|c|c|c|c|c|c|c|}
\hline \multirow{2}{*}{ Híbrido } & \multirow{2}{*}{ Tratamento } & \multicolumn{7}{|c|}{ Momento de avaliação (dia) } & \multirow{2}{*}{\multicolumn{2}{|c|}{ Média }} \\
\hline & & $3^{\mathrm{o}}$ & & $4^{\mathrm{O}}$ & & $5^{\mathrm{o}}$ & $6^{\mathrm{o}}$ & $7^{\underline{0}}$ & & \\
\hline \multirow{5}{*}{ H1R } & Controle & 98 & & 93 & & 98 & 100 & 97 & 97 & $\mathrm{AB}$ \\
\hline & fungicida & 99 & & 98 & & 100 & 100 & 99 & 99 & $\mathrm{~A}$ \\
\hline & fungicida + inseticida & 97 & & 95 & & 97 & 99 & 97 & 97 & $\mathrm{AB}$ \\
\hline & $\begin{array}{l}\text { fungicida }+ \text { inseticida }+ \\
\text { nematicida }\end{array}$ & 97 & & 94 & & 95 & 98 & 97 & 96 & $\mathrm{~B}$ \\
\hline & Média & 98 & $\mathrm{a}$ & 95 & $\mathrm{~b}$ & $98 \mathrm{ab}$ & 99 a & $97 \mathrm{ab}$ & $\mathrm{CV} \%$ & 2,78 \\
\hline \multirow{5}{*}{$\mathrm{H} 2 \mathrm{R}$} & Controle & 96 & & 91 & & 97 & 96 & 98 & 96 & $\mathrm{~B}$ \\
\hline & fungicida & 98 & & 98 & & 97 & 99 & 100 & 98 & A \\
\hline & fungicida + inseticida & 96 & & 98 & & 98 & 99 & 95 & 97 & $\mathrm{AB}$ \\
\hline & $\begin{array}{l}\text { fungicida }+ \text { inseticida }+ \\
\text { nematicida }\end{array}$ & 96 & & 97 & & 96 & 98 & 95 & 96 & $\mathrm{AB}$ \\
\hline & Média & 96 & $\mathrm{a}$ & 96 & $\mathrm{a}$ & $97 \mathrm{a}$ & 98 a & $97 \mathrm{a}$ & $\mathrm{CV} \%$ & 2,96 \\
\hline \multirow{5}{*}{$\mathrm{H} 3 \mathrm{R}$} & Controle & 100 & & 99 & & 99 & 99 & 100 & 99 & $\mathrm{~A}$ \\
\hline & fungicida & 100 & & 100 & & 100 & 100 & 100 & 100 & $\mathrm{~A}$ \\
\hline & fungicida + inseticida & 98 & & 99 & & 99 & 99 & 99 & 99 & $\mathrm{~A}$ \\
\hline & $\begin{array}{l}\text { fungicida }+ \text { inseticida }+ \\
\text { nematicida }\end{array}$ & 99 & & 100 & & 99 & 100 & 99 & 99 & $\mathrm{~A}$ \\
\hline & Média & 99 & $\mathrm{a}$ & 99 & $\mathrm{a}$ & 99 a & 99 a & 99 a & $\mathrm{CV} \%$ & 1,21 \\
\hline \multirow{5}{*}{$\mathrm{H} 1 \mathrm{C}$} & Controle & 100 & & 98 & & 100 & 100 & 99 & 99 & $\mathrm{~A}$ \\
\hline & fungicida & 99 & & 100 & & 99 & 100 & 100 & 99 & A \\
\hline & fungicida + inseticida & 100 & & 98 & & 100 & 100 & 100 & 99 & $\mathrm{~A}$ \\
\hline & $\begin{array}{l}\text { fungicida }+ \text { inseticida }+ \\
\text { nematicida }\end{array}$ & 99 & & 99 & & 100 & 100 & 100 & 100 & $\mathrm{~A}$ \\
\hline & Média & 99 & $a b$ & 99 & $\mathrm{~b}$ & $100 \mathrm{a}$ & $100 \mathrm{a}$ & $100 \mathrm{a}$ & $\mathrm{CV} \%$ & 1,00 \\
\hline \multirow{5}{*}{$\mathrm{H} 2 \mathrm{C}$} & Controle & 90 & & 96 & & 88 & 95 & 91 & 92 & $\mathrm{~A}$ \\
\hline & fungicida & 93 & & 89 & & 93 & 90 & 92 & 91 & A \\
\hline & fungicida + inseticida & 92 & & 94 & & 96 & 93 & 87 & 90 & A \\
\hline & $\begin{array}{l}\text { fungicida }+ \text { inseticida }+ \\
\text { nematicida }\end{array}$ & 90 & & 92 & & 89 & 90 & 91 & 90 & $\mathrm{~A}$ \\
\hline & Média & 91 & $\mathrm{a}$ & 93 & $\mathrm{a}$ & 89 a & $92 \mathrm{a}$ & $90 \mathrm{a}$ & $\mathrm{CV} \%$ & 5,15 \\
\hline \multirow{5}{*}{$\mathrm{H} 3 \mathrm{C}$} & Controle & 99 & & 100 & & 100 & 100 & 100 & 100 & $\mathrm{~A}$ \\
\hline & fungicida & 99 & & 99 & & 99 & 100 & 96 & 98 & A \\
\hline & Fungicida + inseticida & 100 & & 98 & & 100 & 99 & 100 & 99 & A \\
\hline & $\begin{array}{l}\text { fungicida }+ \text { inseticida }+ \\
\text { nematicida }\end{array}$ & 100 & & 100 & & 99 & 98 & 100 & 99 & $\mathrm{~A}$ \\
\hline & Média & 99 & $\mathrm{a}$ & 99 & $\mathrm{a}$ & $99 \mathrm{a}$ & 99 a & $99 \mathrm{a}$ & $\mathrm{CV} \%$ & 1,73 \\
\hline
\end{tabular}

Médias seguidas pela mesma letra maiúscula na coluna e minúscula na linha não diferem estatisticamente entre si, para cada híbrido e forma das sementes, pelo teste de Tukey $(\alpha=0,05)$. CV\% $=$ coeficiente de variação. 
Para comparar resultados das repetições do mesmo teste de germinação foram utilizadas as Tabelas de Tolerância das Regras para Análise de Sementes (BRASIL, 2009), que são utilizadas rotineiramente para a verificação entre resultados das sementes comercializadas.

As tolerâncias máximas admitidas, Tabela 18.9 das RAS (ISTA, 1963 citado por BRASIL, 2009), entre os resultados do teste de germinação das repetições de 50 sementes de milho H1R, H2R, H3R, H1C, H2C e H3C (Tabelas 5 a 10) foram calculadas a partir da diferença entre o maior e menor valor das repetições (Máximo-Mínimo).

A diferença entre os resultados das repetições de 50 sementes do teste de germinação é inferior à tolerância para todos os híbridos, independentemente do momento de avaliação e tratamento. Portanto, as variações dos resultados estão de acordo com os limites estabelecidos nas tolerâncias das RAS. 
Tabela 5. Tolerâncias máximas descritas nas RAS entre os resultados do teste de germinação das sementes híbridas de milho H1R, repetições de 50 sementes

\begin{tabular}{|c|c|c|c|c|}
\hline $\begin{array}{l}\text { Momento de } \\
\text { avaliação }\end{array}$ & Tratamento & $\mathrm{G}(\%)$ & $\begin{array}{l}\text { Máximo- } \\
\text { Mínimo }\end{array}$ & Tolerância \\
\hline \multirow{4}{*}{$3^{0}$ dia } & Controle & 98 & 2 & 6 \\
\hline & fungicida & 99 & 1 & 5 \\
\hline & fungicida + inseticida & 97 & 4 & 7 \\
\hline & fungicida + inseticida + nematicida & 97 & 4 & 7 \\
\hline \multirow{4}{*}{$4^{\circ} \stackrel{\text { dia }}{ }$} & Controle & 93 & 3 & 10 \\
\hline & fungicida & 98 & 2 & 6 \\
\hline & fungicida + inseticida & 95 & 0 & 9 \\
\hline & fungicida + inseticida + nematicida & 94 & 4 & 10 \\
\hline \multirow{4}{*}{$5^{-0}$ dia } & Controle & 98 & 2 & 6 \\
\hline & fungicida & 100 & 0 & - \\
\hline & fungicida + inseticida & 97 & 2 & 7 \\
\hline & fungicida + inseticida + nematicida & 95 & 0 & 9 \\
\hline \multirow{4}{*}{$6^{\underline{o}}$ dia } & Controle & 100 & 0 & - \\
\hline & fungicida & 100 & 0 & - \\
\hline & fungicida + inseticida & 99 & 1 & 5 \\
\hline & fungicida + inseticida + nematicida & 98 & 1 & 6 \\
\hline \multirow{4}{*}{$7^{0}$ dia } & Controle & 97 & 0 & 7 \\
\hline & fungicida & 99 & 1 & 5 \\
\hline & fungicida + inseticida & 97 & 4 & 7 \\
\hline & fungicida + inseticida + nematicida & 97 & 2 & 7 \\
\hline
\end{tabular}

$\mathrm{G}=$ média de germinação; Máximo-Mínimo = diferença entre o maior e o menor valor das repetições. 
Tabela 6. Tolerâncias máximas descritas nas RAS entre os resultados do teste de germinação das sementes híbridas de milho H2R, repetições de 50 sementes

\begin{tabular}{|c|c|c|c|c|}
\hline $\begin{array}{l}\text { Momento de } \\
\text { avaliação }\end{array}$ & Tratamento & $\mathrm{G}(\%)$ & Máximo-Mínimo & Tolerância \\
\hline \multirow{4}{*}{$3^{\underline{o}}$ dia } & Controle & 96 & 4 & 8 \\
\hline & fungicida & 98 & 2 & 6 \\
\hline & fungicida + inseticida & 96 & 4 & 8 \\
\hline & fungicida + inseticida + nematicida & 96 & 1 & 8 \\
\hline \multirow{4}{*}{$4^{\underline{o}}$ dia } & Controle & 91 & 6 & 11 \\
\hline & fungicida & 98 & 0 & 6 \\
\hline & fungicida + inseticida & 98 & 1 & 6 \\
\hline & fungicida + inseticida + nematicida & 97 & 3 & 7 \\
\hline \multirow{4}{*}{$5^{-0}$ dia } & Controle & 97 & 0 & 7 \\
\hline & fungicida & 97 & 4 & 7 \\
\hline & fungicida + inseticida & 98 & 2 & 6 \\
\hline & fungicida + inseticida + nematicida & 96 & 4 & 8 \\
\hline \multirow{4}{*}{$6^{-}$dia } & Controle & 96 & 3 & 8 \\
\hline & fungicida & 99 & 1 & 5 \\
\hline & fungicida + inseticida & 99 & 1 & 5 \\
\hline & fungicida + inseticida + nematicida & 98 & 1 & 6 \\
\hline \multirow{4}{*}{$7^{\underline{0}}$ dia } & Controle & 98 & 2 & 6 \\
\hline & fungicida & 100 & 1 & - \\
\hline & fungicida + inseticida & 95 & 2 & 9 \\
\hline & fungicida + inseticida + nematicida & 95 & 2 & 9 \\
\hline
\end{tabular}

$\mathrm{G}$ = média de germinação; Máximo-Mínimo = diferença entre o maior e o menor valor das repetições. 
Tabela 7. Tolerâncias máximas descritas nas RAS entre os resultados do teste de germinação das sementes híbridas de milho H3R, repetições de 50 sementes

\begin{tabular}{|c|c|c|c|c|}
\hline $\begin{array}{c}\text { Momento de } \\
\text { avaliação }\end{array}$ & Tratamento & $\mathrm{G}(\%)$ & Máximo-Mínimo & Tolerância \\
\hline \multirow{4}{*}{$3^{o}$ dia } & Controle & 100 & 0 & - \\
\hline & fungicida & 100 & 1 & - \\
\hline & fungicida + inseticida & 98 & 0 & 6 \\
\hline & fungicida + inseticida + nematicida & 99 & 0 & 5 \\
\hline \multirow{4}{*}{$4^{\underline{o}}$ dia } & Controle & 99 & 0 & 5 \\
\hline & fungicida & 100 & 1 & - \\
\hline & fungicida + inseticida & 99 & 2 & 5 \\
\hline & fungicida + inseticida + nematicida & 100 & 1 & - \\
\hline \multirow{4}{*}{$5^{o} \mathrm{dia}$} & Controle & 99 & 0 & 5 \\
\hline & fungicida & 100 & 1 & - \\
\hline & fungicida + inseticida & 99 & 1 & 5 \\
\hline & fungicida + inseticida + nematicida & 99 & 1 & 5 \\
\hline \multirow{4}{*}{$6^{\mathrm{o}} \mathrm{dia}$} & Controle & 99 & 2 & 5 \\
\hline & fungicida & 100 & 0 & - \\
\hline & fungicida + inseticida & 99 & 0 & 5 \\
\hline & fungicida + inseticida + nematicida & 100 & 1 & - \\
\hline \multirow{4}{*}{$7^{\mathrm{o}} \mathrm{dia}$} & Controle & 100 & 0 & - \\
\hline & fungicida & 100 & 1 & - \\
\hline & fungicida + inseticida & 99 & 1 & 5 \\
\hline & fungicida + inseticida + nematicida & 99 & 1 & 5 \\
\hline
\end{tabular}

$\mathrm{G}$ = média de germinação; Máximo-Mínimo = diferença entre o maior e o menor valor das repetições. 
Tabela 8. Tolerâncias máximas descritas nas RAS entre os resultados do teste de germinação das sementes híbridas de milho $\mathrm{H} 1 \mathrm{C}$, repetições de 50 sementes

\begin{tabular}{|c|c|c|c|c|}
\hline $\begin{array}{c}\text { Momento } \\
\text { de avaliação }\end{array}$ & Tratamento & $\mathrm{G}(\%)$ & Máximo-Mínimo & Tolerância \\
\hline \multirow{4}{*}{$3^{-0}$ dia } & Controle & 100 & 1 & - \\
\hline & fungicida & 99 & 0 & 5 \\
\hline & fungicida + inseticida & 100 & 1 & - \\
\hline & fungicida + inseticida + nematicida & 99 & 2 & 5 \\
\hline \multirow{4}{*}{$4^{\mathrm{o}}$ dia } & Controle & 98 & 2 & 6 \\
\hline & fungicida & 100 & 1 & - \\
\hline & fungicida + inseticida & 98 & 1 & 6 \\
\hline & fungicida + inseticida + nematicida & 99 & 2 & 5 \\
\hline \multirow{4}{*}{$5^{\underline{o}}$ dia } & Controle & 100 & 0 & - \\
\hline & fungicida & 99 & 2 & 5 \\
\hline & fungicida + inseticida & 100 & 1 & - \\
\hline & fungicida + inseticida + nematicida & 100 & 0 & - \\
\hline \multirow{4}{*}{$6^{-}$dia } & Controle & 100 & 0 & - \\
\hline & fungicida & 100 & 1 & - \\
\hline & fungicida + inseticida & 100 & 0 & - \\
\hline & fungicida + inseticida + nematicida & 100 & 1 & - \\
\hline \multirow{4}{*}{$7^{\mathrm{o}} \mathrm{dia}$} & Controle & 99 & 1 & 5 \\
\hline & fungicida & 100 & 1 & - \\
\hline & fungicida + inseticida & 100 & 0 & - \\
\hline & fungicida + inseticida + nematicida & 100 & 0 & - \\
\hline
\end{tabular}

$\mathrm{G}=$ média de germinação; Máximo-Mínimo = diferença entre o maior e o menor valor das repetições. 
Tabela 9. Tolerâncias máximas descritas nas RAS entre os resultados do teste de germinação das sementes híbridas de milho $\mathrm{H} 2 \mathrm{C}$, repetições de 50 sementes

\begin{tabular}{|c|c|c|c|c|}
\hline $\begin{array}{l}\text { Momento de } \\
\text { avaliação }\end{array}$ & Tratamento & $\mathrm{G}(\%)$ & Máximo-Mínimo & Tolerância \\
\hline \multirow{4}{*}{$3^{o}$ dia } & Controle & 90 & 1 & 12 \\
\hline & fungicida & 93 & 3 & 10 \\
\hline & fungicida + inseticida & 92 & 3 & 11 \\
\hline & fungicida + inseticida + nematicida & 90 & 3 & 12 \\
\hline \multirow{4}{*}{$4^{\underline{o}}$ dia } & Controle & 96 & 3 & 8 \\
\hline & fungicida & 89 & 0 & 12 \\
\hline & fungicida + inseticida & 94 & 4 & 10 \\
\hline & fungicida + inseticida + nematicida & 92 & 3 & 11 \\
\hline \multirow{4}{*}{$5^{-0}$ dia } & Controle & 88 & 5 & 13 \\
\hline & fungicida & 93 & 5 & 10 \\
\hline & fungicida + inseticida & 86 & 5 & 14 \\
\hline & fungicida + inseticida + nematicida & 89 & 1 & 12 \\
\hline \multirow{4}{*}{$6^{-}$dia } & Controle & 95 & 4 & 9 \\
\hline & fungicida & 90 & 0 & 12 \\
\hline & fungicida + inseticida & 93 & 6 & 10 \\
\hline & fungicida + inseticida + nematicida & 90 & 8 & 12 \\
\hline \multirow{4}{*}{$7^{\mathrm{o}} \mathrm{dia}$} & Controle & 91 & 0 & 11 \\
\hline & fungicida & 92 & 3 & 11 \\
\hline & fungicida + inseticida & 87 & 7 & 13 \\
\hline & fungicida + inseticida + nematicida & 91 & 3 & 11 \\
\hline
\end{tabular}

G = média de germinação; Máximo-Mínimo = diferença entre o maior e o menor valor das repetições. 
Tabela 10. Tolerâncias máximas descritas nas RAS entre os resultados do teste de germinação das sementes híbridas de milho H3C, repetições de 50 sementes

\begin{tabular}{|c|c|c|c|c|}
\hline $\begin{array}{l}\text { Momento de } \\
\text { avaliação }\end{array}$ & Tratamento & $\mathrm{G}(\%)$ & Máximo-Mínimo & Tolerância \\
\hline \multirow{4}{*}{$3^{o}$ dia } & Controle & 100 & 1 & - \\
\hline & fungicida & 99 & 0 & 5 \\
\hline & fungicida + inseticida & 100 & 1 & - \\
\hline & fungicida + inseticida + nematicida & 99 & 2 & 5 \\
\hline \multirow{4}{*}{$4^{\underline{0}}$ dia } & Controle & 98 & 2 & 6 \\
\hline & fungicida & 100 & 1 & - \\
\hline & fungicida + inseticida & 98 & 1 & 6 \\
\hline & fungicida + inseticida + nematicida & 99 & 2 & 5 \\
\hline \multirow{4}{*}{$5^{-0}$ dia } & Controle & 100 & 0 & - \\
\hline & fungicida & 99 & 2 & 5 \\
\hline & fungicida + inseticida & 100 & 1 & - \\
\hline & fungicida + inseticida + nematicida & 100 & 0 & - \\
\hline \multirow{4}{*}{$6^{-0}$ dia } & Controle & 100 & 0 & - \\
\hline & fungicida & 100 & 1 & - \\
\hline & fungicida + inseticida & 100 & 0 & - \\
\hline & fungicida + inseticida + nematicida & 100 & 1 & - \\
\hline \multirow{4}{*}{$7^{\mathrm{o}} \mathrm{dia}$} & Controle & 99 & 1 & 5 \\
\hline & fungicida & 100 & 1 & - \\
\hline & fungicida + inseticida & 100 & 0 & - \\
\hline & fungicida + inseticida + nematicida & 100 & 0 & - \\
\hline
\end{tabular}

$\mathrm{G}=$ média de germinação; Máximo-Mínimo = diferença entre o maior e o menor valor das repetições.

$\mathrm{Na}$ análise de variância, os valores da probabilidade (p) para a interação entre os fatores tratamento e momento de avaliação para o teste de germinação das repetições de 25 sementes são maiores que 0,05 (Tabela 11 ), ou seja, a interação não é significativa $(\alpha=0,05)$.

Tabela 11. Probabilidade (p) da interação entre os fatores momento de avaliação e tratamento para o teste de germinação das repetições de 25 sementes

\begin{tabular}{cccccc}
\hline H1R & H2R & H3R & H1C & H2C & H3C \\
\hline 0,1592 & 0,2451 & 0,4149 & 0,5182 & 0,4894 & 0,8258 \\
\hline
\end{tabular}

Portanto, os fatores analisados são independentes e não interferem nos resultados da análise (Tabela 12). 
Tabela 12. Germinação de sementes de milho (\%) por tratamento e momento de avaliação nas repetições de 25 sementes

\begin{tabular}{|c|c|c|c|c|c|c|c|c|}
\hline \multirow{2}{*}{ Híbrido } & \multirow{2}{*}{ Tratamento } & \multicolumn{5}{|c|}{ Momento de avaliação (dia) } & \multirow{2}{*}{\multicolumn{2}{|c|}{ Média }} \\
\hline & & $3^{-}$ & $4^{\mathrm{O}}$ & $5^{\mathrm{o}}$ & $6^{0}$ & $7^{0}$ & & \\
\hline \multirow{5}{*}{$\mathrm{H} 1 \mathrm{R}$} & Controle & 98 & 96 & 97 & 100 & 97 & 97 & \\
\hline & fungicida & 99 & 99 & 100 & 100 & 97 & 99 & A \\
\hline & fungicida + inseticida & 97 & 98 & 96 & 98 & 99 & 98 & A \\
\hline & $\begin{array}{l}\text { fungicida }+ \text { inseticida } \\
+ \text { nematicida }\end{array}$ & 98 & 97 & 98 & 98 & 98 & & \\
\hline & Média & $98 \mathrm{a}$ & $97 \mathrm{a}$ & $98 \mathrm{a}$ & 99 a & $97 \mathrm{a}$ & $\mathrm{CV} \%$ & 2,89 \\
\hline \multirow{5}{*}{$\mathrm{H} 2 \mathrm{R}$} & Controle & 97 & 96 & 95 & 99 & 97 & 97 & \\
\hline & fungicida & 93 & 97 & 99 & 99 & 98 & 97 & \\
\hline & fungicida + inseticida & 94 & 96 & 97 & 98 & 95 & 96 & A \\
\hline & $\begin{array}{l}\text { fungicida }+ \text { inseticida } \\
+ \text { nematicida }\end{array}$ & 97 & 93 & 98 & 96 & 96 & 96 & \\
\hline & Média & $95 \mathrm{a}$ & $95 \mathrm{a}$ & $97 \mathrm{a}$ & $98 \mathrm{a}$ & 96 a & $\mathrm{CV} \%$ & 4,52 \\
\hline \multirow{5}{*}{ H3R } & Controle & 99 & 100 & 99 & 99 & 100 & 99 & $\mathrm{AB}$ \\
\hline & fungicida & 99 & 100 & 100 & 100 & 100 & 100 & A \\
\hline & fungicida + inseticida & 99 & 100 & 99 & 99 & 100 & 99 & $\mathrm{AB}$ \\
\hline & $\begin{array}{l}\text { fungicida }+ \text { inseticida } \\
+ \text { nematicida }\end{array}$ & 99 & 99 & 98 & 100 & 98 & 99 & B \\
\hline & Média & $99 \mathrm{a}$ & $100 \mathrm{a}$ & $99 \mathrm{a}$ & $99 \mathrm{a}$ & $99 \mathrm{a}$ & $\mathrm{CV} \%$ & 1,76 \\
\hline \multirow{5}{*}{$\mathrm{H} 1 \mathrm{C}$} & Controle & 99 & 100 & 99 & 99 & 100 & 99 & \\
\hline & fungicida & 100 & 99 & 98 & 100 & 100 & 99 & A \\
\hline & fungicida + inseticida & 99 & 100 & 99 & 100 & 100 & 99 & A \\
\hline & $\begin{array}{l}\text { fungicida }+ \text { inseticida } \\
+ \text { nematicida }\end{array}$ & 100 & 99 & 100 & 100 & 100 & 99 & A \\
\hline & Média & $99 \mathrm{a}$ & $99 \mathrm{a}$ & 99 a & $99 \mathrm{a}$ & $100 \mathrm{a}$ & $\mathrm{CV} \%$ & 1,65 \\
\hline \multirow{5}{*}{$\mathrm{H} 2 \mathrm{C}$} & Controle & 94 & 93 & 90 & 94 & 91 & 92 & \\
\hline & fungicida & 96 & 94 & 91 & 89 & 91 & 92 & \\
\hline & fungicida + inseticida & 94 & 92 & 87 & 94 & 90 & 91 & A \\
\hline & $\begin{array}{l}\text { fungicida }+ \text { inseticida } \\
+ \text { nematicida }\end{array}$ & 88 & 96 & 88 & 89 & 87 & 89 & A \\
\hline & Média & $93 \mathrm{ab}$ & $94 \mathrm{a}$ & $89 \mathrm{~b}$ & $91 \mathrm{ab}$ & $90 \mathrm{ab}$ & $\mathrm{CV} \%$ & 7,10 \\
\hline \multirow{5}{*}{$\mathrm{H} 3 \mathrm{C}$} & Controle & 99 & 99 & 99 & 100 & 99 & 99 & $\mathrm{~B}$ \\
\hline & fungicida & 100 & 100 & 100 & 100 & 99 & 100 & $\mathrm{~A}$ \\
\hline & fungicida + inseticida & 100 & 99 & 100 & 100 & 100 & 100 & $\mathrm{AB}$ \\
\hline & $\begin{array}{l}\text { fungicida }+ \text { inseticida } \\
+ \text { nematicida }\end{array}$ & 99 & 100 & 100 & 100 & 100 & 100 & $\mathrm{AB}$ \\
\hline & Média & $99 \mathrm{a}$ & $99 \mathrm{a}$ & $100 \mathrm{a}$ & $100 \mathrm{a}$ & $99 \mathrm{a}$ & $\mathrm{CV} \%$ & 1,43 \\
\hline
\end{tabular}

Médias seguidas pela mesma letra maiúscula na coluna e minúscula na linha não diferem estatisticamente entre si, para cada híbrido e forma das sementes, pelo teste de Tukey $(\alpha=0,05)$. CV\% = coeficiente de variação. 
As análises da germinação utilizando 50 ou 25 sementes de milho por repetição indicaram que, além da avaliação no $4^{-0}$ e $7^{\underline{0}}$ dia após a semeadura, conforme as RAS, também é possível avaliar a germinação das sementes de milho tratadas no $5^{\mathrm{o}}$ ou $6^{\mathrm{o}}$ dia após a semeadura ou antecipar a avaliação para o $3^{\circ}$ dia após a semeadura, sem alteração de resultado (Tabelas 4 e 12).

A tabela de Tolerância 18.9 das RAS foi utilizada para comparar os resultados das repetições de H1R, H2R, H3R, H1C, H2C e H3C (Tabelas 13 a 18), a partir da diferença entre o maior e menor valor das repetições (Máximo-Mínimo).

A diferença entre os resultados das repetições de 25 sementes do teste de germinação também é inferior à tolerância para todos os híbridos, independentemente do momento de avaliação e do tratamento. Portanto, não há diferença significativa entre os resultados, de acordo com as tolerâncias das RAS.

Tabela 13. Tolerâncias máximas descritas nas RAS entre os resultados do teste de germinação das sementes híbridas de milho H1R, repetições de 25 sementes

\begin{tabular}{|c|c|c|c|c|}
\hline $\begin{array}{l}\text { Momento de } \\
\text { avaliação }\end{array}$ & Tratamento & $\mathrm{G}(\%)$ & Máximo-Mínimo & Tolerância \\
\hline \multirow{4}{*}{$3^{0}$ dia } & Controle & 98 & 1 & 6 \\
\hline & fungicida & 99 & 1 & 5 \\
\hline & fungicida + inseticida & 97 & 6 & 7 \\
\hline & fungicida + inseticida + nematicida & 98 & 1 & 6 \\
\hline \multirow{4}{*}{$4^{\mathrm{o}} \mathrm{dia}$} & Controle & 96 & 3 & 8 \\
\hline & fungicida & 99 & 2 & 5 \\
\hline & fungicida + inseticida & 98 & 0 & 6 \\
\hline & fungicida + inseticida + nematicida & 97 & 0 & 7 \\
\hline \multirow{4}{*}{$5^{-0}$ dia } & Controle & 97 & 0 & 7 \\
\hline & fungicida & 100 & 0 & - \\
\hline & fungicida + inseticida & 96 & 0 & 8 \\
\hline & fungicida + inseticida + nematicida & 98 & 2 & 6 \\
\hline \multirow{4}{*}{$6^{-}$dia } & Controle & 100 & 1 & - \\
\hline & fungicida & 100 & 0 & - \\
\hline & fungicida + inseticida & 98 & 0 & 6 \\
\hline & fungicida + inseticida + nematicida & 98 & 2 & 6 \\
\hline \multirow{4}{*}{$7^{\underline{0}} \mathrm{dia}$} & Controle & 97 & 3 & 7 \\
\hline & fungicida & 97 & 1 & 7 \\
\hline & fungicida + inseticida & 99 & 2 & 5 \\
\hline & fungicida + inseticida + nematicida & 98 & 1 & 6 \\
\hline
\end{tabular}

G = média de germinação; Máximo-Mínimo = diferença entre o maior e o menor valor das repetições. 
Tabela 14. Tolerâncias máximas descritas nas RAS entre os resultados do teste de germinação das sementes híbridas de milho H2R, repetições de 25 sementes

\begin{tabular}{|c|c|c|c|c|}
\hline $\begin{array}{l}\text { Momento de } \\
\text { avaliação }\end{array}$ & Tratamento & $\mathrm{G}(\%)$ & Máximo-Mínimo & Tolerância \\
\hline \multirow{4}{*}{$3^{o}$ dia } & Controle & 97 & 1 & 7 \\
\hline & fungicida & 93 & 1 & 10 \\
\hline & fungicida + inseticida & 94 & 2 & 10 \\
\hline & fungicida + inseticida + nematicida & 97 & 4 & 7 \\
\hline \multirow{4}{*}{$4^{\underline{o}}$ dia } & Controle & 96 & 4 & 8 \\
\hline & fungicida & 97 & 2 & 7 \\
\hline & fungicida + inseticida & 96 & 3 & 8 \\
\hline & fungicida + inseticida + nematicida & 93 & 0 & 10 \\
\hline \multirow{4}{*}{$5^{-0}$ dia } & Controle & 95 & 4 & 9 \\
\hline & fungicida & 99 & 1 & 5 \\
\hline & fungicida + inseticida & 97 & 1 & 7 \\
\hline & fungicida + inseticida + nematicida & 98 & 0 & 6 \\
\hline \multirow{4}{*}{$6^{\underline{o}}$ dia } & Controle & 99 & 1 & 5 \\
\hline & fungicida & 99 & 1 & 5 \\
\hline & fungicida + inseticida & 98 & 5 & 6 \\
\hline & fungicida + inseticida + nematicida & 96 & 2 & 8 \\
\hline \multirow{4}{*}{$7^{\mathrm{o}} \mathrm{dia}$} & Controle & 97 & 0 & 7 \\
\hline & fungicida & 98 & 1 & 6 \\
\hline & fungicida + inseticida & 95 & 2 & 9 \\
\hline & fungicida + inseticida + nematicida & 96 & 0 & 8 \\
\hline
\end{tabular}

G = média de germinação; Máximo-Mínimo = diferença entre o maior e o menor valor das repetições. 
Tabela 15. Tolerâncias máximas descritas nas RAS entre os resultados do teste de germinação das sementes híbridas de milho H3R, repetições de 25 sementes

\begin{tabular}{|c|c|c|c|c|}
\hline $\begin{array}{l}\text { Momento de } \\
\text { avaliação }\end{array}$ & Tratamento & $\mathrm{G}(\%)$ & Máximo-Mínimo & Tolerância \\
\hline \multirow{4}{*}{$3^{-0}$ dia } & Controle & 99 & 1 & 5 \\
\hline & fungicida & 99 & 0 & 5 \\
\hline & fungicida + inseticida & 99 & 0 & 5 \\
\hline & fungicida + inseticida + nematicida & 99 & 1 & 5 \\
\hline \multirow{4}{*}{$4^{\underline{o}}$ dia } & Controle & 100 & 0 & - \\
\hline & fungicida & 100 & 0 & - \\
\hline & fungicida + inseticida & 100 & 1 & - \\
\hline & fungicida + inseticida + nematicida & 99 & 0 & 5 \\
\hline \multirow{4}{*}{$5^{-}$dia } & Controle & 99 & 1 & 5 \\
\hline & fungicida & 100 & 0 & - \\
\hline & fungicida + inseticida & 99 & 0 & 5 \\
\hline & fungicida + inseticida + nematicida & 98 & 1 & 6 \\
\hline \multirow{4}{*}{$6^{-}$dia } & Controle & 99 & 2 & 5 \\
\hline & fungicida & 100 & 0 & - \\
\hline & fungicida + inseticida & 99 & 1 & 5 \\
\hline & fungicida + inseticida + nematicida & 100 & 0 & - \\
\hline \multirow{4}{*}{$7^{\mathrm{o}} \mathrm{dia}$} & Controle & 100 & 1 & - \\
\hline & fungicida & 100 & 1 & - \\
\hline & fungicida + inseticida & 100 & 1 & - \\
\hline & fungicida + inseticida + nematicida & 98 & 2 & 6 \\
\hline
\end{tabular}

$\mathrm{G}$ = média de germinação; Máximo-Mínimo = diferença entre o maior e o menor valor das repetições. 
Tabela 16. Tolerâncias máximas descritas nas RAS entre os resultados do teste de germinação das sementes híbridas de milho H1C, repetições de 25 sementes

\begin{tabular}{|c|c|c|c|c|}
\hline $\begin{array}{l}\text { Momento de } \\
\text { avaliação }\end{array}$ & Tratamento & $\mathrm{G}(\%)$ & Máximo-Mínimo & Tolerância \\
\hline \multirow{4}{*}{$3^{-0}$ dia } & Controle & 99 & 0 & 5 \\
\hline & fungicida & 100 & 0 & - \\
\hline & fungicida + inseticida & 99 & 0 & 5 \\
\hline & fungicida + inseticida + nematicida & 100 & 1 & - \\
\hline \multirow{4}{*}{$4^{\underline{0}}$ dia } & Controle & 100 & 1 & - \\
\hline & fungicida & 99 & 2 & 5 \\
\hline & fungicida + inseticida & 100 & 1 & - \\
\hline & fungicida + inseticida + nematicida & 99 & 0 & 5 \\
\hline \multirow{4}{*}{$5^{\mathrm{o}} \mathrm{dia}$} & Controle & 99 & 0 & 5 \\
\hline & fungicida & 98 & 0 & 6 \\
\hline & fungicida + inseticida & 99 & 1 & 5 \\
\hline & fungicida + inseticida + nematicida & 100 & 1 & - \\
\hline \multirow{4}{*}{$6^{-}$dia } & Controle & 99 & 1 & 5 \\
\hline & fungicida & 100 & 1 & - \\
\hline & fungicida + inseticida & 100 & 1 & - \\
\hline & fungicida + inseticida + nematicida & 100 & 0 & - \\
\hline \multirow{4}{*}{$7^{0}$ dia } & Controle & 100 & 1 & - \\
\hline & fungicida & 100 & 0 & - \\
\hline & fungicida + inseticida & 100 & 1 & - \\
\hline & fungicida + inseticida + nematicida & 100 & 1 & - \\
\hline
\end{tabular}

$\mathrm{G}=$ média de germinação; Máximo-Mínimo = diferença entre o maior e o menor valor das repetições. 
Tabela 17. Tolerâncias máximas descritas nas RAS entre os resultados do teste de germinação das sementes híbridas de milho H2C, repetições de 25 sementes

\begin{tabular}{|c|c|c|c|c|}
\hline $\begin{array}{l}\text { Momento de } \\
\text { avaliação }\end{array}$ & Tratamento & $\mathrm{G}(\%)$ & Máximo-Mínimo & Tolerância \\
\hline \multirow{4}{*}{$3^{-0}$ dia } & Controle & 94 & 1 & 10 \\
\hline & fungicida & 96 & 3 & 8 \\
\hline & fungicida + inseticida & 94 & 3 & 10 \\
\hline & fungicida + inseticida + nematicida & 88 & 2 & 13 \\
\hline \multirow{4}{*}{$4^{\circ}$ dia } & Controle & 93 & 6 & 10 \\
\hline & fungicida & 94 & 3 & 10 \\
\hline & fungicida + inseticida & 92 & 8 & 11 \\
\hline & fungicida + inseticida + nematicida & 96 & 0 & 8 \\
\hline \multirow{4}{*}{$5^{\circ} \mathrm{dia}$} & Controle & 90 & 1 & 12 \\
\hline & fungicida & 91 & 1 & 11 \\
\hline & fungicida + inseticida & 87 & 2 & 13 \\
\hline & fungicida + inseticida + nematicida & 88 & 6 & 13 \\
\hline \multirow{4}{*}{$6^{-} \mathrm{dia}$} & Controle & 94 & 0 & 10 \\
\hline & fungicida & 89 & 1 & 12 \\
\hline & fungicida + inseticida & 94 & 1 & 10 \\
\hline & fungicida + inseticida + nematicida & 89 & 1 & 12 \\
\hline \multirow{4}{*}{$7^{0}$ dia } & Controle & 91 & 5 & 11 \\
\hline & fungicida & 91 & 0 & 11 \\
\hline & fungicida + inseticida & 90 & 6 & 12 \\
\hline & fungicida + inseticida + nematicida & 87 & 10 & 13 \\
\hline
\end{tabular}

$\mathrm{G}$ = média de germinação; Máximo-Mínimo = diferença entre o maior e o menor valor das repetições. 
Tabela 18. Tolerâncias máximas descritas nas RAS entre os resultados do teste de germinação das sementes híbridas de milho $\mathrm{H} 3 \mathrm{C}$, repetições de 25 sementes

\begin{tabular}{|c|c|c|c|c|}
\hline $\begin{array}{l}\text { Momento de } \\
\text { avaliação }\end{array}$ & Tratamento & $\mathrm{G}(\%)$ & Máximo-Mínimo & Tolerância \\
\hline \multirow{4}{*}{$3^{-0}$ dia } & Controle & 99 & 1 & 5 \\
\hline & fungicida & 100 & 0 & - \\
\hline & fungicida + inseticida & 100 & 1 & - \\
\hline & fungicida + inseticida + nematicida & 99 & 0 & 5 \\
\hline \multirow{4}{*}{$4^{\underline{o}}$ dia } & Controle & 99 & 3 & 5 \\
\hline & fungicida & 100 & 1 & - \\
\hline & fungicida + inseticida & 99 & 2 & 5 \\
\hline & fungicida + inseticida + nematicida & 100 & 0 & - \\
\hline \multirow{4}{*}{$5^{-} \mathrm{dia}$} & Controle & 99 & 1 & 5 \\
\hline & fungicida & 100 & 0 & - \\
\hline & fungicida + inseticida & 100 & 1 & - \\
\hline & fungicida + inseticida + nematicida & 100 & 0 & - \\
\hline \multirow{4}{*}{$6^{-}$dia } & Controle & 100 & 1 & - \\
\hline & fungicida & 100 & 0 & - \\
\hline & fungicida + inseticida & 100 & 1 & - \\
\hline & fungicida + inseticida + nematicida & 100 & 0 & - \\
\hline \multirow{4}{*}{$7^{0} \mathrm{dia}$} & Controle & 99 & 2 & 5 \\
\hline & fungicida & 99 & 2 & 5 \\
\hline & fungicida + inseticida & 100 & 0 & - \\
\hline & fungicida + inseticida + nematicida & 100 & 1 & - \\
\hline
\end{tabular}

$\mathrm{G}$ = média de germinação; Máximo-Mínimo = diferença entre o maior e o menor valor das repetições.

As tolerâncias máximas admitidas para a comparação de médias do teste de germinação, Tabela 18.10 das RAS (ISTA, 1963 citado por BRASIL, 2009), foram calculadas para os resultados das avaliações das sementes de cada híbrido, das repetições de 50 e 25 sementes (Tabelas 19 a 30). 
Tabela 19. Comparação de resultados do teste de germinação das sementes híbridas de milho H1R, repetições de 50 sementes

\begin{tabular}{lccccc}
\hline \multicolumn{1}{c}{ Comparação } & Germinação (\%) & Média (\%) & Tolerância & Diferença \\
\hline $\begin{array}{l}\text { Controle e } \\
\text { fungicida }\end{array}$ & 97 & 99 & 98 & 2 & 2 \\
$\begin{array}{l}\text { Controle e } \\
\text { fungicida + inseticida }\end{array}$ & 97 & 97 & 97 & 3 & 0 \\
$\begin{array}{l}\text { Controle e } \\
\text { fungicida + inseticida + nematicida }\end{array}$ & 97 & 96 & 97 & 3 & 1 \\
$\begin{array}{l}\text { fungicida e } \\
\text { fungicida + inseticida }\end{array}$ & 99 & 97 & 98 & 2 & 2 \\
$\begin{array}{l}\text { fungicida e } \\
\text { fungicida + inseticida + nematicida }\end{array}$ & 99 & 96 & 98 & 2 & 3 \\
$\begin{array}{l}\text { fungicida + inseticida e } \\
\text { fungicida + inseticida + nematicida }\end{array}$ & 97 & 96 & 97 & 3 & 1 \\
\hline
\end{tabular}

Tolerância: diferença máxima admitida entre os resultados. |Diferença|: módulo da diferença entre as médias dos tratamentos.

Tabela 20. Comparação de resultados do teste de germinação das sementes híbridas de milho $\mathrm{H} 2 \mathrm{R}$, repetições de 50 sementes

\begin{tabular}{lccccc}
\hline \multicolumn{1}{c}{ Comparação } & Germinação (\%) & Média (\%) & Tolerância & Diferença \\
\hline $\begin{array}{l}\text { Controle e } \\
\text { fungicida }\end{array}$ & 96 & 98 & 97 & 3 & 2 \\
$\begin{array}{l}\text { Controle e } \\
\text { fungicida + inseticida }\end{array}$ & 96 & 97 & 97 & 3 & 1 \\
$\begin{array}{l}\text { Controle e } \\
\text { fungicida + inseticida + nematicida }\end{array}$ & 96 & 96 & 96 & 3 & 0 \\
$\begin{array}{l}\text { fungicida e } \\
\text { fungicida + inseticida }\end{array}$ & 98 & 97 & 98 & 2 & 1 \\
$\begin{array}{l}\text { fungicida e } \\
\text { fungicida + inseticida + nematicida }\end{array}$ & 98 & 96 & 97 & 3 & 2 \\
$\begin{array}{l}\text { fungicida + inseticida e } \\
\text { fungicida + inseticida + nematicida }\end{array}$ & 97 & 96 & 97 & 3 & 1 \\
\hline
\end{tabular}

Tolerância: diferença máxima admitida entre os resultados. |Diferença|: módulo da diferença entre as médias dos tratamentos. 
Tabela 21. Comparação de resultados do teste de germinação das sementes híbridas de milho H3R, repetições de 50 sementes

\begin{tabular}{|c|c|c|c|c|c|}
\hline Comparação & \multicolumn{2}{|c|}{ Germinação (\%) } & Média (\%) & Tolerância & |Diferença| \\
\hline $\begin{array}{l}\text { Controle e } \\
\text { fungicida }\end{array}$ & 99 & 100 & 100 & - & 1 \\
\hline $\begin{array}{l}\text { Controle e } \\
\text { fungicida }+ \text { inseticida }\end{array}$ & 99 & 99 & 99 & 2 & 0 \\
\hline $\begin{array}{l}\text { Controle e } \\
\text { fungicida }+ \text { inseticida }+ \text { nematicida }\end{array}$ & 99 & 99 & 99 & 2 & 0 \\
\hline $\begin{array}{l}\text { fungicida e } \\
\text { fungicida }+ \text { inseticida }\end{array}$ & 100 & 99 & 100 & - & 1 \\
\hline $\begin{array}{l}\text { fungicida e } \\
\text { fungicida }+ \text { inseticida }+ \text { nematicida }\end{array}$ & 100 & 99 & 100 & - & 1 \\
\hline $\begin{array}{l}\text { fungicida }+ \text { inseticida e } \\
\text { fungicida }+ \text { inseticida }+ \text { nematicida }\end{array}$ & 99 & 99 & 99 & 2 & 0 \\
\hline
\end{tabular}

Tolerância: diferença máxima admitida entre os resultados. |Diferença|: módulo da diferença entre as médias dos tratamentos.

Tabela 22. Comparação de resultados do teste de germinação das sementes híbridas de milho $\mathrm{H} 1 \mathrm{C}$, repetições de 50 sementes

\begin{tabular}{lccccc}
\hline \multicolumn{1}{c}{ Comparação } & Germinação (\%) & Média (\%) & Tolerância & Diferença| \\
\hline $\begin{array}{l}\text { Controle e } \\
\text { fungicida }\end{array}$ & 99 & 99 & 99 & 2 & 0 \\
$\begin{array}{l}\text { Controle e } \\
\text { fungicida + inseticida }\end{array}$ & 99 & 99 & 99 & 2 & 0 \\
$\begin{array}{l}\text { Controle e } \\
\text { fungicida + inseticida + nematicida }\end{array}$ & 99 & 100 & 100 & - & 1 \\
$\begin{array}{l}\text { fungicida e } \\
\text { fungicida + inseticida }\end{array}$ & 99 & 99 & 99 & 2 & 0 \\
$\begin{array}{l}\text { fungicida e } \\
\text { fungicida + inseticida + nematicida }\end{array}$ & 99 & 100 & 100 & - & 1 \\
$\begin{array}{l}\text { fungicida + inseticida e } \\
\text { fungicida + inseticida + nematicida }\end{array}$ & 99 & 100 & 100 & - & 1 \\
\hline
\end{tabular}

Tolerância: diferença máxima admitida entre os resultados. |Diferença|: módulo da diferença entre as médias dos tratamentos. 
Tabela 23. Comparação de resultados do teste de germinação das sementes híbridas de milho $\mathrm{H} 2 \mathrm{C}$, repetições de 50 sementes

\begin{tabular}{lccccc}
\hline \multicolumn{1}{c}{ Comparação } & Germinação (\%) & Média (\%) & Tolerância & Diferença \\
\hline $\begin{array}{l}\text { Controle e } \\
\text { fungicida }\end{array}$ & 92 & 91 & 92 & 4 & 1 \\
$\begin{array}{l}\text { Controle e } \\
\text { fungicida + inseticida }\end{array}$ & 92 & 90 & 91 & 4 & 2 \\
$\begin{array}{l}\text { Controle e } \\
\text { fungicida + inseticida + nematicida }\end{array}$ & 92 & 90 & 91 & 4 & 2 \\
$\begin{array}{l}\text { fungicida e } \\
\text { fungicida + inseticida }\end{array}$ & 91 & 90 & 91 & 4 & 1 \\
$\begin{array}{l}\text { fungicida e } \\
\text { fungicida + inseticida + nematicida }\end{array}$ & 91 & 90 & 91 & 4 & 1 \\
$\begin{array}{l}\text { fungicida + inseticida e } \\
\text { fungicida + inseticida + nematicida }\end{array}$ & 90 & 90 & 90 & 5 & 0 \\
\hline
\end{tabular}

Tolerância: diferença máxima admitida entre os resultados. |Diferença|: módulo da diferença entre as médias dos tratamentos.

Tabela 24. Comparação de resultados do teste de germinação das sementes híbridas de milho $\mathrm{H} 3 \mathrm{C}$, repetições de 50 sementes

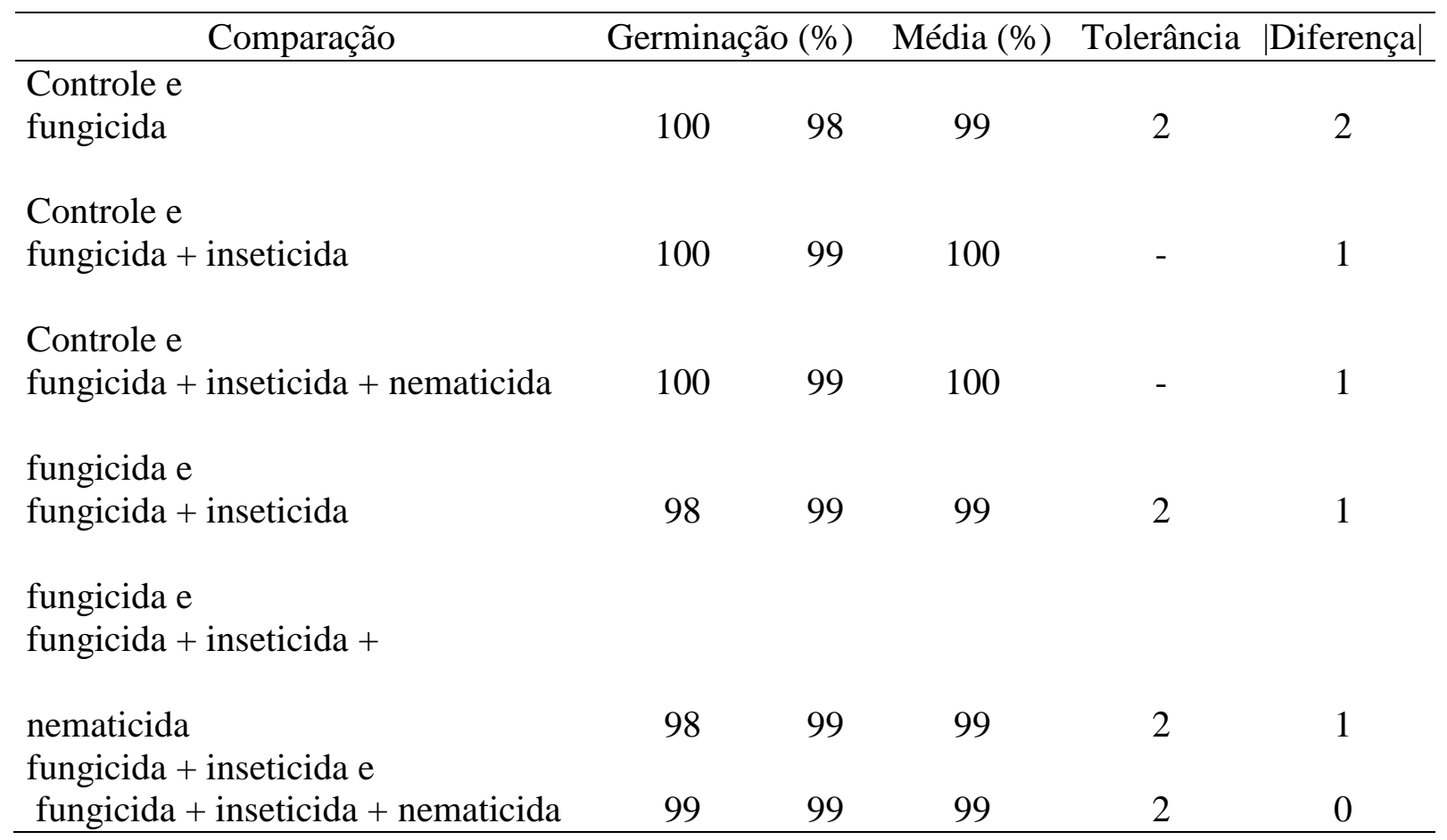

Tolerância: diferença máxima admitida entre os resultados. |Diferença|: módulo da diferença entre as médias dos tratamentos. 
Tabela 25. Comparação de resultados do teste de germinação das sementes híbridas de milho $\mathrm{H} 1 \mathrm{R}$, repetições de 25 sementes

\begin{tabular}{lccccc}
\hline \multicolumn{1}{c}{ Comparação } & Germinação (\%) & Média (\%) & Tolerância & Diferença| \\
\hline $\begin{array}{l}\text { Controle e } \\
\text { fungicida }\end{array}$ & 97 & 99 & 98 & 2 & 2 \\
$\begin{array}{l}\text { Controle e } \\
\text { fungicida + inseticida }\end{array}$ & 97 & 98 & 98 & 2 & 1 \\
$\begin{array}{l}\text { Controle e } \\
\text { fungicida + inseticida + nematicida }\end{array}$ & 97 & 98 & 98 & 2 & 1 \\
$\begin{array}{l}\text { fungicida e } \\
\text { fungicida + inseticida }\end{array}$ & 99 & 98 & 99 & 2 & 1 \\
$\begin{array}{l}\text { fungicida e } \\
\text { fungicida + inseticida + nematicida }\end{array}$ & 99 & 98 & 99 & 2 & 1 \\
$\begin{array}{l}\text { fungicida + inseticida e } \\
\text { fungicida + inseticida + nematicida }\end{array}$ & 98 & 98 & 98 & 2 & 0 \\
\hline
\end{tabular}

Tolerância: diferença máxima admitida entre os resultados. |Diferença|: módulo da diferença entre as médias dos tratamentos.

Tabela 26. Comparação de resultados do teste de germinação das sementes híbridas de milho $\mathrm{H} 2 \mathrm{R}$, repetições de 25 sementes

\begin{tabular}{lccccc}
\hline \multicolumn{1}{c}{ Comparação } & Germinação (\%) & Média (\%) & Tolerância & Diferença| \\
\hline $\begin{array}{l}\text { Controle e } \\
\text { fungicida }\end{array}$ & 97 & 97 & 97 & 3 & 0 \\
$\begin{array}{l}\text { Controle e } \\
\text { fungicida + inseticida }\end{array}$ & 97 & 96 & 97 & 3 & 1 \\
$\begin{array}{l}\text { Controle e } \\
\text { fungicida + inseticida + nematicida }\end{array}$ & 97 & 96 & 97 & 3 & 1 \\
$\begin{array}{l}\text { fungicida e } \\
\text { fungicida + inseticida }\end{array}$ & 97 & 96 & 97 & 3 & 1 \\
$\begin{array}{l}\text { fungicida e } \\
\text { fungicida + inseticida + nematicida }\end{array}$ & 97 & 96 & 97 & 3 & 1 \\
$\begin{array}{l}\text { fungicida + inseticida e } \\
\text { fungicida + inseticida + nematicida }\end{array}$ & 96 & 96 & 96 & 3 & 0 \\
\hline
\end{tabular}

Tolerância: diferença máxima admitida entre os resultados. |Diferença|: módulo da diferença entre as médias dos tratamentos. 
Tabela 27. Comparação de resultados do teste de germinação das sementes híbridas de milho H3R, repetições de 25 sementes

\begin{tabular}{lccccc}
\hline \multicolumn{1}{c}{ Comparação } & Germinação (\%) & $\begin{array}{c}\text { Média } \\
(\%)\end{array}$ & Tolerância & $\mid$ Diferença $\mid$ \\
\hline $\begin{array}{l}\text { Controle e } \\
\text { fungicida }\end{array}$ & 99 & 100 & 100 & - & 1 \\
$\begin{array}{l}\text { Controle e } \\
\text { fungicida + inseticida }\end{array}$ & 99 & 99 & 99 & 2 & 0 \\
$\begin{array}{l}\text { Controle e } \\
\text { fungicida + inseticida + nematicida }\end{array}$ & 99 & 99 & 99 & 2 & 0 \\
$\begin{array}{l}\text { fungicida e } \\
\text { fungicida + inseticida }\end{array}$ & 100 & 99 & 100 & - & 1 \\
$\begin{array}{l}\text { fungicida e } \\
\text { fungicida + inseticida + nematicida }\end{array}$ & 100 & 99 & 100 & - & 1 \\
$\begin{array}{l}\text { fungicida + inseticida e } \\
\text { fungicida + inseticida + nematicida }\end{array}$ & 99 & 99 & 99 & 2 & 0 \\
\hline
\end{tabular}

Tolerância: diferença máxima admitida entre os resultados. |Diferença|: módulo da diferença entre as médias dos tratamentos. 
Tabela 28. Comparação de resultados do teste de germinação das sementes híbridas de milho $\mathrm{H} 1 \mathrm{C}$, repetições de 25 sementes

\begin{tabular}{lccccc}
\hline \multicolumn{1}{c}{ Comparação } & Germinação (\%) & Média (\%) & Tolerância & |Diferença \\
\hline $\begin{array}{l}\text { Controle e } \\
\text { fungicida }\end{array}$ & 99 & 99 & 99 & 2 & 0 \\
$\begin{array}{l}\text { Controle e } \\
\text { fungicida + inseticida }\end{array}$ & 99 & 99 & 99 & 2 & 0 \\
$\begin{array}{l}\text { Controle e } \\
\text { fungicida + inseticida + nematicida }\end{array}$ & 99 & 99 & 99 & 2 & 0 \\
$\begin{array}{l}\text { fungicida e } \\
\text { fungicida + inseticida }\end{array}$ & 99 & 99 & 99 & 2 & 0 \\
$\begin{array}{l}\text { fungicida e } \\
\text { fungicida + inseticida + nematicida }\end{array}$ & 99 & 99 & 99 & 2 & 0 \\
$\begin{array}{l}\text { fungicida + inseticida e } \\
\text { fungicida + inseticida + nematicida }\end{array}$ & 99 & 99 & 99 & 2 & 0 \\
\hline
\end{tabular}

Tolerância: diferença máxima admitida entre os resultados. |Diferença|: módulo da diferença entre as médias dos tratamentos.

Tabela 29. Comparação de resultados do teste de germinação das sementes híbridas de milho $\mathrm{H} 2 \mathrm{C}$, repetições de 25 sementes

\begin{tabular}{lccccc}
\hline \multicolumn{1}{c}{ Comparação } & Germinação (\%) & Média (\%) & Tolerância & Diferençal \\
\hline $\begin{array}{l}\text { Controle e } \\
\text { fungicida }\end{array}$ & 92 & 92 & 92 & 4 & 0 \\
$\begin{array}{l}\text { Controle e } \\
\text { fungicida + inseticida }\end{array}$ & 92 & 91 & 92 & 4 & 1 \\
$\begin{array}{l}\text { Controle e } \\
\text { fungicida + inseticida + } \\
\text { nematicida }\end{array}$ & 92 & 89 & 91 & 4 & 3 \\
$\begin{array}{l}\text { fungicida e } \\
\text { fungicida + inseticida }\end{array}$ & 92 & 91 & 92 & 4 & 1 \\
$\begin{array}{l}\text { fungicida e } \\
\text { fungicida + inseticida + nematicida }\end{array}$ & 92 & 89 & 91 & 4 & 3 \\
$\begin{array}{l}\text { fungicida + inseticida e } \\
\text { fungicida + inseticida + nematicida }\end{array}$ & 91 & 89 & 90 & 5 & 2 \\
\hline
\end{tabular}

Tolerância: diferença máxima admitida entre os resultados. |Diferença|: módulo da diferença entre as médias dos tratamentos. 
Tabela 30. Comparação de resultados do teste de germinação das sementes híbridas de milho $\mathrm{H} 3 \mathrm{C}$, repetições de 25 sementes

\begin{tabular}{|c|c|c|c|c|c|}
\hline Comparação & Germin & $(\%)$ & Média (\%) & Tolerância & |Diferença| \\
\hline $\begin{array}{l}\text { Controle e } \\
\text { fungicida }\end{array}$ & 99 & 100 & 100 & - & 1 \\
\hline $\begin{array}{l}\text { Controle e } \\
\text { fungicida }+ \text { inseticida }\end{array}$ & 99 & 100 & 100 & - & 1 \\
\hline $\begin{array}{l}\text { Controle e } \\
\text { fungicida }+ \text { inseticida }+ \text { nematicida }\end{array}$ & 99 & 100 & 100 & - & 1 \\
\hline $\begin{array}{l}\text { fungicida e } \\
\text { fungicida }+ \text { inseticida }\end{array}$ & 100 & 100 & 100 & - & 0 \\
\hline $\begin{array}{l}\text { fungicida e } \\
\text { fungicida }+ \text { inseticida }+ \text { nematicida }\end{array}$ & 100 & 100 & 100 & - & 0 \\
\hline $\begin{array}{l}\text { fungicida }+ \text { inseticida } \mathrm{e} \\
\text { fungicida }+ \text { inseticida }+ \text { nematicida }\end{array}$ & 100 & 100 & 100 & - & 0 \\
\hline
\end{tabular}

Tolerância: diferença máxima admitida entre os resultados. |Diferença|: módulo da diferença entre as médias dos tratamentos.

As diferenças entre as médias de germinação dos tratamentos são inferiores às tolerâncias admitidas, ou seja, os resultados são válidos para comparação entre os tratamentos, exceto para a comparação entre os tratamentos fungicida e fungicida + inseticida + nematicida para o híbrido H1R, nas repetições de 50 sementes.

Todos os resultados de germinação obtidos neste trabalho são superiores ao mínimo de $85 \%$ para a comercialização de sementes híbridas de milho (MAPA, 2013). No Brasil, há empresas que comercializam sementes de milho com germinação mínima superior a 90\%, devido à tecnologia de produção das sementes de milho, que possibilita a colheita das sementes com alta qualidade fisiológica (PESKE; MENEGUELLO, 2013). Para que o tratamento industrial seja eficiente, as sementes devem apresentar alta qualidade fisiológica (PESKE et. al, 2016).

Na maioria das comparações entre as médias de germinação das sementes de milho, os resultados das avaliações de cada híbrido são compatíveis, ou seja, não houve diferença significativa entre o Controle e os tratamentos com fungicida, inseticida e nematicida, de acordo com as tolerâncias indicadas na tabela 18.10 das RAS.

Melo et. al (2010) verificaram que a testemunha (sem tratamento químico) e os tratamentos com fungicida e inseticida não diferiram estatisticamente entre si, quanto à 
germinação das sementes de milho em substrato areia, avaliados no $5^{\circ}$ dia após a instalação do teste. Magalhães (2013) avaliou a germinação de sementes híbridas comerciais de milho tratadas com nematicida, fungicida e fungicida + inseticida, além da testemunha, e verificou que não houve diferença estatística significativa entre os tratamentos após 45 e 90 dias de armazenamento.

$\mathrm{Na}$ interação entre o momento da avaliação e o comprimento médio da raiz nas repetições de 50 sementes de milho (Tabelas 31 e 32) houve variação nos resultados. E nas repetições de 25 sementes de milho (Tabelas 33 e 34) a interação não foi significativa para todos os híbridos analisados. Portanto, o número de sementes de milho tratadas utilizadas no teste de germinação pode interferir no crescimento da raiz da plântula, dependendo do genótipo.

Foi possível observar diferenças visuais entre as plântulas das repetições de 25 e 50 sementes, uma vez que, quanto mais sementes são colocadas no papel, menor é o espaçamento entre elas e, para as sementes tratadas, maior é a quantidade de produtos químicos na mesma área do papel de germinação, o que causou a redução do crescimento e o escurecimento das raízes, quando o teste foi avaliado em algumas repetições de 50 sementes; entretanto, esses fatores não interferiram no resultado do teste de germinação. Ou seja, para avaliar sementes tratadas de milho é possível utilizar 50 sementes por repetição ou 25 sementes por repetição, embora a colocação das 25 sementes favoreça a avaliação do desenvolvimento das plântulas.

Houve diferença estatística significativa entre os momentos de avaliação em relação às avaliações do comprimento médio de raiz, porque há o aumento do comprimento da raiz na medida em que aumenta o período de avaliação (Tabelas 31 a 34). 
Tabela 31. Comprimento médio $(\mathrm{cm})$ da raiz nas repetições de 50 sementes híbridas de milho, 1,2 e 3 , classificadas como redondas (R), do $3^{\circ}$ ao $7^{0}$ dia após a semeadura

\begin{tabular}{|c|c|c|c|c|c|c|c|c|}
\hline \multirow{2}{*}{ Híbrido } & \multirow{2}{*}{ Tratamento } & \multicolumn{5}{|c|}{ Momento de avaliação (dia) } & \multirow{2}{*}{\multicolumn{2}{|c|}{ Média }} \\
\hline & & $3^{\underline{o}}$ & $4^{\mathrm{O}}$ & $5^{\mathrm{o}}$ & $6^{\mathrm{o}}$ & $7^{\underline{0}}$ & & \\
\hline \multirow{5}{*}{$\mathrm{H} 1 \mathrm{R}$} & Controle & 5,0 & 9,0 & 12,0 & 15,4 & 17,4 & 11,8 & $\mathrm{~B}$ \\
\hline & fungicida & 5,7 & 9,4 & 15,0 & 17,1 & 17,2 & 12,9 & A \\
\hline & $\begin{array}{l}\text { fungicida }+ \\
\text { inseticida }\end{array}$ & 5,7 & 9,4 & 13,4 & 15,5 & 16,1 & 12,0 & $\mathrm{AB}$ \\
\hline & $\begin{array}{l}\text { fungicida }+ \\
\text { inseticida }+ \\
\text { nematicida }\end{array}$ & 6,2 & 9,1 & 12,7 & 14,7 & 17,0 & \multirow{2}{*}{$\begin{array}{l}11,9 \\
\text { CV\% }\end{array}$} & $\mathrm{AB}$ \\
\hline & Média & $5,7 \mathrm{e}$ & $9,3 \mathrm{~d}$ & $13,3 \mathrm{c}$ & $15,7 \mathrm{~b}$ & 16,9 a & & 9,43 \\
\hline \multirow{5}{*}{$\mathrm{H} 2 \mathrm{R}$} & Controle & $7,8 \mathrm{dA}$ & $11,3 \mathrm{cA}$ & $16,5 \mathrm{bAB}$ & $15,4 \mathrm{bB}$ & 18,9 aA & 14,0 & \\
\hline & fungicida & $6,9 \mathrm{cA}$ & $12,8 \mathrm{bA}$ & 18,2 aA & 19,6 aA & 19,9 aA & 15,5 & \\
\hline & $\begin{array}{l}\text { fungicida }+ \\
\text { inseticida }\end{array}$ & $7,3 \mathrm{dA}$ & $12,2 \mathrm{cA}$ & $16,2 \mathrm{bB}$ & 18,4 aA & 18,3 aA & 14,5 & \\
\hline & $\begin{array}{l}\text { fungicida }+ \\
\text { inseticida }+ \\
\text { nematicida }\end{array}$ & $7,1 \mathrm{dA}$ & $11,1 \mathrm{cA}$ & $15,9 \mathrm{bB}$ & 18,0 aA & 19,7 aA & \multicolumn{2}{|l|}{14,4} \\
\hline & Média & 7,3 & 11,9 & 16,7 & 17,9 & 19,2 & $\mathrm{CV} \%$ & 6,97 \\
\hline \multirow{5}{*}{ H3R } & Controle & 6,8 & 11,4 & 16,0 & 18,4 & 21,4 & 14,8 & A \\
\hline & fungicida & 6,3 & 10,7 & 16,0 & 18,4 & 20,3 & 14,3 & A \\
\hline & $\begin{array}{l}\text { fungicida }+ \\
\text { inseticida }\end{array}$ & 7,2 & 12,3 & 17,1 & 18,3 & 20,2 & 15,0 & $\mathrm{~A}$ \\
\hline & $\begin{array}{l}\text { fungicida }+ \\
\text { inseticida }+ \\
\text { nematicida }\end{array}$ & 6,7 & 12,1 & 15,8 & 18,2 & 19,2 & \multirow{2}{*}{\multicolumn{2}{|c|}{$14,4 \mathrm{~A}$}} \\
\hline & Média & $6,7 \mathrm{e}$ & $11,7 \mathrm{~d}$ & $16,3 \mathrm{c}$ & $18,3 \mathrm{~b}$ & 20,3 a & & \\
\hline
\end{tabular}

Médias seguidas pela mesma letra maiúscula na coluna e minúscula na linha não diferem estatisticamente entre si, para cada híbrido, pelo teste de Tukey $(\alpha=0,05)$. CV\% = coeficiente de variação. 
Tabela 32. Comprimento médio $(\mathrm{cm})$ da raiz nas repetições de 50 sementes híbridas de milho, 1,2 e 3 , classificadas como chatas (C), do $3^{\circ}$ ao $7^{\circ}$ dia após a semeadura

\begin{tabular}{|c|c|c|c|c|c|c|c|c|}
\hline \multirow{2}{*}{ Híbrido } & \multirow{2}{*}{ Tratamento } & \multicolumn{5}{|c|}{ Momento de avaliação (dia) } & \multirow{2}{*}{\multicolumn{2}{|c|}{ Média }} \\
\hline & & $3^{\underline{0}}$ & $4^{\mathrm{O}}$ & $5^{\mathrm{o}}$ & $6^{\mathrm{o}}$ & $7^{\underline{0}}$ & & \\
\hline \multirow{5}{*}{$\mathrm{H} 1 \mathrm{C}$} & Controle & 8,9 & 14,3 & 17,7 & 21,0 & 21,1 & 16,6 & A \\
\hline & fungicida & 9,1 & 15,2 & 18,5 & 19,4 & 21,4 & 16,7 & A \\
\hline & $\begin{array}{l}\text { fungicida }+ \\
\text { inseticida }\end{array}$ & 8,2 & 13,5 & 17,5 & 19,8 & 19,3 & 15,7 & $\mathrm{AB}$ \\
\hline & $\begin{array}{l}\text { fungicida }+ \\
\text { inseticida }+ \\
\text { nematicida } \\
\end{array}$ & 8,2 & 13,5 & 18,2 & 18,6 & 18,5 & \multirow{2}{*}{\multicolumn{2}{|c|}{$\begin{array}{c}15,4 \text { B } \\
\text { CV\% } 8,34 \\
\end{array}$}} \\
\hline & Média & $8,6 \mathrm{c}$ & $14,1 \mathrm{~b}$ & $18,0 \mathrm{a}$ & $19,7 \mathrm{a}$ & 20,0 a & & \\
\hline \multirow{5}{*}{$\mathrm{H} 2 \mathrm{C}$} & Controle & $6,1 \mathrm{cA}$ & $12,0 \mathrm{bA}$ & 15,3 aA & 15,6 aA & $14,6 \mathrm{abA}$ & 12,7 & \\
\hline & fungicida & $5,5 \mathrm{cA}$ & 9,9 bAB & $14,7 \mathrm{aAB}$ & 15,1 aA & $16,5 \mathrm{aA}$ & 12,3 & \\
\hline & $\begin{array}{l}\text { fungicida }+ \\
\text { inseticida }\end{array}$ & $5,2 \mathrm{cA}$ & 9,8 bAB & $11,9 \mathrm{bB}$ & 15,3 aA & $11,6 \mathrm{bB}$ & 10,8 & \\
\hline & $\begin{array}{l}\text { fungicida }+ \\
\text { inseticida }+ \\
\text { nematicida }\end{array}$ & 5,8 bA & $8,6 \mathrm{bB}$ & $13,1 \mathrm{aAB}$ & 13,0 aA & 14,9 aA & \multicolumn{2}{|l|}{11,1} \\
\hline & Média & 5,7 & 10,0 & 13,8 & 14,8 & 14,4 & CV\% & 12,87 \\
\hline \multirow{5}{*}{$\mathrm{H} 3 \mathrm{C}$} & Controle & 7,5 & 14,3 & 18,5 & 20,8 & 20,8 & 16,4 & A \\
\hline & fungicida & 7,7 & 13,5 & 16,9 & 18,5 & 17,5 & 14,8 & $\mathrm{~B}$ \\
\hline & $\begin{array}{l}\text { fungicida + } \\
\text { inseticida }\end{array}$ & 7,6 & 12,8 & 17,1 & 16,7 & 17,8 & 14,4 & B \\
\hline & $\begin{array}{l}\text { fungicida }+ \\
\text { inseticida }+ \\
\text { nematicida }\end{array}$ & 7,1 & 12,6 & 17,9 & 18,0 & 20,2 & \multirow{2}{*}{\multicolumn{2}{|c|}{$15,1 \quad \mathrm{AB}$}} \\
\hline & Média & $7,5 \mathrm{c}$ & $13,3 \mathrm{~b}$ & 17,6 a & $18,5 \mathrm{a}$ & $19,1 \mathrm{a}$ & & \\
\hline
\end{tabular}

Médias seguidas pela mesma letra maiúscula na coluna e minúscula na linha não diferem estatisticamente entre si, para cada híbrido, pelo teste de Tukey $(\alpha=0,05)$. CV\% = coeficiente de variação. 
Tabela 33. Comprimento médio $(\mathrm{cm})$ da raiz nas repetições de 25 sementes híbridas de milho, 1,2 e 3 , classificadas como redondas (R), do $3^{\circ}$ ao $7^{0}$ dia após a semeadura

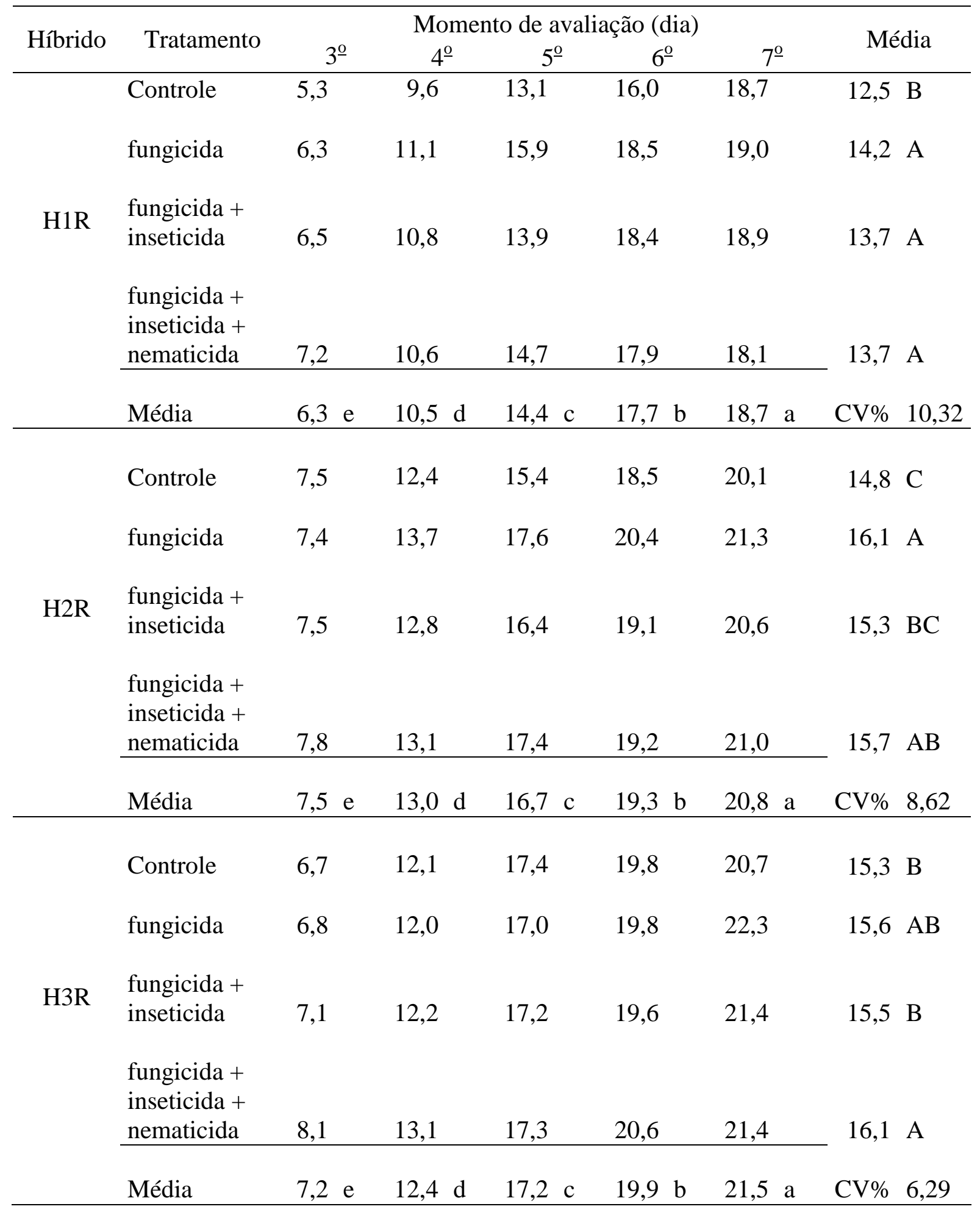

Médias seguidas pela mesma letra maiúscula na coluna e minúscula na linha não diferem estatisticamente entre si, para cada híbrido, pelo teste de Tukey $(\alpha=0,05)$. CV\% = coeficiente de variação. 
Tabela 34. Comprimento médio $(\mathrm{cm})$ da raiz nas repetições de 25 sementes híbridas de milho, 1,2 e 3 , classificadas como chatas (C), do $3^{\circ}$ ao $7^{\circ}$ dia após a semeadura

\begin{tabular}{|c|c|c|c|c|c|c|c|c|}
\hline \multirow{2}{*}{ Híbrido } & \multirow{2}{*}{ Tratamento } & \multicolumn{5}{|c|}{ Momento de avaliação (dia) } & \multirow{2}{*}{\multicolumn{2}{|c|}{ Média }} \\
\hline & & $3^{\mathrm{o}}$ & $4^{\mathrm{o}}$ & $5^{\mathrm{o}}$ & $6^{\mathrm{o}}$ & $7^{\underline{0}}$ & & \\
\hline \multirow{5}{*}{$\mathrm{H} 1 \mathrm{C}$} & Controle & 9,0 & 14,4 & 19,9 & 21,5 & 22,4 & 17,4 & \\
\hline & fungicida & 9,5 & 14,6 & 18,6 & 21,1 & 23,3 & 17,4 & A \\
\hline & $\begin{array}{l}\text { fungicida }+ \\
\text { inseticida }\end{array}$ & 8,1 & 14,4 & 18,7 & 20,5 & 22,6 & 16,9 & $\mathrm{AB}$ \\
\hline & $\begin{array}{l}\text { fungicida }+ \\
\text { inseticida }+ \\
\text { nematicida }\end{array}$ & 9,3 & 13,5 & 18,1 & 20,8 & 21,8 & \multirow{2}{*}{\multicolumn{2}{|c|}{$\begin{array}{c}16,7 \text { B } \\
\text { CV\% }\end{array}$}} \\
\hline & Média & $9,0 \mathrm{e}$ & $14,2 \mathrm{~d}$ & $18,8 \mathrm{c}$ & $21,0 \mathrm{~b}$ & $22,5 \mathrm{a}$ & & \\
\hline \multirow{5}{*}{$\mathrm{H} 2 \mathrm{C}$} & Controle & 6,4 & 11,9 & 14,8 & 17,1 & 17,6 & 13,5 & A \\
\hline & fungicida & 6,7 & 11,6 & 15,4 & 17,0 & 17,1 & 13,6 & A \\
\hline & $\begin{array}{l}\text { fungicida }+ \\
\text { inseticida }\end{array}$ & 6,6 & 10,5 & 14,4 & 18,1 & 17,0 & 13,3 & A \\
\hline & $\begin{array}{l}\text { fungicida }+ \\
\text { inseticida }+ \\
\text { nematicida }\end{array}$ & 5,9 & 10,9 & 14,4 & 16,7 & 17,5 & \multirow{2}{*}{\multicolumn{2}{|c|}{ CV\% 11,41}} \\
\hline & Média & $6,4 \mathrm{~d}$ & $11,3 \mathrm{c}$ & $14,8 \mathrm{~b}$ & $17,2 \mathrm{a}$ & $17,3 \mathrm{a}$ & & \\
\hline \multirow{5}{*}{$\mathrm{H} 3 \mathrm{C}$} & Controle & 7,7 & 14,3 & 19,3 & 21,6 & 22,4 & 17,1 & \\
\hline & fungicida & 8,5 & 13,9 & 17,5 & 20,6 & 21,8 & 16,5 & B \\
\hline & $\begin{array}{l}\text { fungicida }+ \\
\text { inseticida }\end{array}$ & 8,2 & 14,1 & 19,2 & 21,7 & 22,5 & 17,1 & A \\
\hline & $\begin{array}{l}\text { fungicida }+ \\
\text { inseticida }+ \\
\text { nematicida }\end{array}$ & 8,0 & 13,8 & 18,7 & 20,6 & 21,3 & \multirow{2}{*}{\multicolumn{2}{|c|}{ CV\% $\quad 6,13$}} \\
\hline & Média & $8,1 \mathrm{e}$ & $14,0 \mathrm{~d}$ & $18,7 \mathrm{c}$ & $21,1 \mathrm{~b}$ & $22,0 \mathrm{a}$ & & \\
\hline
\end{tabular}

Médias seguidas pela mesma letra maiúscula na coluna e minúscula na linha não diferem estatisticamente entre si, para cada híbrido, pelo teste de Tukey $(\alpha=0,05)$. CV\% = coeficiente de variação. 
Os resultados do índice de velocidade de germinação (IVG) não diferiram estatisticamente, em função dos tratamentos, para a maioria das sementes analisadas, exceto para o H2R nas repetições de 50 sementes de milho, no qual o resultado com fungicida foi superior aos demais. Quanto ao tempo médio de germinação (TMG), não houve diferença estatística significativa entre os tratamentos químicos em relação ao Controle para todas as sementes analisadas nas repetições de 50 ou 25 sementes de milho. Entretanto, para os híbrido H1R nas repetições de 25 sementes de milho, houve diferença estatística significativa para o TMG entre os tratamentos fungicida e fungicida + inseticida. Portanto, a combinação de produtos químicos para o tratamento das sementes pode alterar os resultados da análise do IVG e do TMG (Tabelas 35 a 38).

O tratamento de sementes não interferiu na emergência da plântula (EP) e no índice de velocidade de emergência da plântula (IVE), independentemente do híbrido ou do número de sementes por repetição. O tempo médio de emergência (TME) não diferiu estatisticamente entre os tratamentos para os híbridos analisados, exceto para o H3R nas repetições de 25 sementes, no qual houve diferença estatística significativa ente os tratamentos fungicida e fungicida + inseticida. Ou seja, a combinação de produtos para o tratamento das sementes pode alterar também os resultados da análise do TME (Tabelas 33 e 34). 
Tabela 35. Índice de velocidade de germinação (IVG), tempo médio de germinação (TMG), emergência da plântula (EP), índice de velocidade de emergência (IVE) e tempo médio de emergência (TME) nas repetições de 50 sementes de milho, classificadas como redondas (R)

\begin{tabular}{|c|c|c|c|c|c|c|c|c|c|}
\hline Híbrido & Tratamento & IVG & & $\begin{array}{l}\text { TMG } \\
\text { (dias) }\end{array}$ & $\begin{array}{l}\mathrm{EP} \\
(\%)\end{array}$ & & IVE & & $\begin{array}{l}\text { TME } \\
\text { (dias) }\end{array}$ \\
\hline \multirow{5}{*}{ H1R } & Controle & 16,15 & $\mathrm{~A}$ & $2,99 \mathrm{~A}$ & 99 & A & 8,31 & $\mathrm{~A}$ & $5,98 \mathrm{~A}$ \\
\hline & fungicida & 16,45 & A & $2,97 \mathrm{~A}$ & 99 & A & 8,30 & A & $5,95 \mathrm{~A}$ \\
\hline & $\begin{array}{l}\text { fungicida }+ \\
\text { inseticida }\end{array}$ & 16,13 & A & $3,00 \mathrm{~A}$ & 99 & A & 8,26 & A & $6,04 \mathrm{~A}$ \\
\hline & $\begin{array}{l}\text { fungicida }+ \\
\text { inseticida }+ \\
\text { nematicida }\end{array}$ & 16,06 & A & $3,05 \mathrm{~A}$ & 98 & A & 8,16 & $\mathrm{~A}$ & $6,00 \mathrm{~A}$ \\
\hline & $\mathrm{CV} \%$ & 1,88 & & 2,67 & 1,37 & & 1,56 & & 0,98 \\
\hline \multirow{5}{*}{$\mathrm{H} 2 \mathrm{R}$} & Controle & 16,03 & B & $3,12 \mathrm{~A}$ & 99 & A & 13,59 & A & $3,78 \mathrm{~A}$ \\
\hline & fungicida & 16,43 & A & $3,07 \mathrm{~A}$ & 98 & A & 12,28 & A & $4,12 \mathrm{~A}$ \\
\hline & $\begin{array}{l}\text { fungicida }+ \\
\text { inseticida }\end{array}$ & 16,03 & B & $2,89 \mathrm{~A}$ & 98 & A & 12,75 & $\mathrm{~A}$ & $3,95 \mathrm{~A}$ \\
\hline & $\begin{array}{l}\text { fungicida }+ \\
\text { inseticida }+ \\
\text { nematicida }\end{array}$ & 15,94 & $\mathrm{~B}$ & $2,94 \mathrm{~A}$ & 97 & A & 11,59 & A & $4,31 \mathrm{~A}$ \\
\hline & CV\% & 1,08 & & 3,95 & 1,91 & & 9,60 & & 8,60 \\
\hline \multirow{5}{*}{ H3R } & Controle & 16,61 & A & $3,03 \mathrm{~A}$ & 98 & A & 11,87 & A & $4,14 \mathrm{~A}$ \\
\hline & fungicida & 16,59 & A & $2,99 \mathrm{~A}$ & 99 & A & 12,10 & A & $4,12 \mathrm{~A}$ \\
\hline & $\begin{array}{l}\text { fungicida }+ \\
\text { inseticida }\end{array}$ & 16,41 & A & $2,99 \mathrm{~A}$ & 99 & A & 11,76 & A & $4,24 \mathrm{~A}$ \\
\hline & $\begin{array}{l}\text { fungicida }+ \\
\text { inseticida }+ \\
\text { nematicida }\end{array}$ & 16,47 & A & $2,97 \mathrm{~A}$ & 98 & A & 11,65 & A & $4,24 \mathrm{~A}$ \\
\hline & $\mathrm{CV} \%$ & 0,60 & & 1,22 & 1,97 & & 3,07 & & 1,97 \\
\hline
\end{tabular}

Médias seguidas pela mesma letra maiúscula na coluna não diferem estatisticamente entre si, para cada híbrido, pelo teste de Tukey $(\alpha=0,05)$. CV\% = coeficiente de variação. 
Tabela 36. Índice de velocidade de germinação (IVG), tempo médio de germinação (TMG), emergência da plântula (EP), índice de velocidade de emergência (IVE) e tempo médio de emergência (TME) nas repetições de 50 sementes de milho, classificadas como chatas (C)

\begin{tabular}{|c|c|c|c|c|c|c|c|c|c|c|c|}
\hline Híbrido & Tratamento & IVG & & $\begin{array}{l}\text { TMG } \\
\text { (dias) }\end{array}$ & & $\begin{array}{l}\mathrm{EP} \\
(\%)\end{array}$ & & IVE & & $\begin{array}{l}\text { TME } \\
\text { (dias) }\end{array}$ & \\
\hline \multirow{5}{*}{$\mathrm{H} 1 \mathrm{C}$} & Controle & 16,49 & A & 2,96 & $\mathrm{~A}$ & 100 & A & 13,09 & A & 3,87 & A \\
\hline & fungicida & 16,55 & A & 3,01 & $\mathrm{~A}$ & 100 & A & 13,55 & A & 3,77 & A \\
\hline & $\begin{array}{l}\text { fungicida }+ \\
\text { inseticida }\end{array}$ & 16,58 & A & 3,04 & A & 99 & $\mathrm{~A}$ & 13,40 & A & 3,75 & A \\
\hline & $\begin{array}{l}\text { fungicida }+ \\
\text { inseticida }+ \\
\text { nematicida }\end{array}$ & 16,59 & $\mathrm{~A}$ & 3,03 & A & 98 & A & 13,10 & A & 3,83 & A \\
\hline & $\mathrm{CV} \%$ & 0,35 & & 1,15 & & 1,60 & & 4,15 & & 2,90 & \\
\hline \multirow{5}{*}{$\mathrm{H} 2 \mathrm{C}$} & Controle & 15,21 & A & 2,96 & A & 92 & A & 8,79 & A & 5,24 & A \\
\hline & fungicida & 15,23 & A & 3,02 & A & 92 & A & 8,84 & A & 5,22 & A \\
\hline & $\begin{array}{l}\text { fungicida }+ \\
\text { inseticida }\end{array}$ & 14,87 & A & 2,78 & A & 96 & A & 9,08 & A & 5,34 & A \\
\hline & $\begin{array}{l}\text { fungicida }+ \\
\text { inseticida }+ \\
\text { nematicida }\end{array}$ & 15,03 & A & 3,02 & A & 93 & A & 8,87 & A & 5,25 & A \\
\hline & $\mathrm{CV} \%$ & 2,22 & & 8,26 & & 4,41 & & 4,90 & & 2,74 & \\
\hline \multirow{5}{*}{$\mathrm{H} 3 \mathrm{C}$} & Controle & 16,57 & A & 2,99 & A & 99 & A & 10,15 & A & 4,91 & A \\
\hline & fungicida & 16,24 & A & 2,85 & A & 100 & A & 10,33 & A & 4,85 & A \\
\hline & $\begin{array}{l}\text { fungicida }+ \\
\text { inseticida }\end{array}$ & 16,56 & A & 3,01 & A & 100 & A & 10,22 & $\mathrm{~A}$ & 4,90 & A \\
\hline & $\begin{array}{l}\text { fungicida }+ \\
\text { inseticida }+ \\
\text { nematicida }\end{array}$ & 16,56 & A & 3,02 & A & 98 & A & 9,99 & A & 4,90 & A \\
\hline & $\mathrm{CV} \%$ & 1,35 & & 2,85 & & 2,13 & & 2,40 & & 1,36 & \\
\hline
\end{tabular}

Médias seguidas pela mesma letra maiúscula na coluna não diferem estatisticamente entre si, para cada híbrido, pelo teste de Tukey $(\alpha=0,05)$. CV\% = coeficiente de variação. 
Tabela 37. Índice de velocidade de germinação (IVG), tempo médio de germinação (TMG), emergência da plântula (EP), índice de velocidade de emergência (IVE) e tempo médio de emergência (TME) nas repetições de 25 sementes de milho, classificadas como redondas (R)

\begin{tabular}{|c|c|c|c|c|c|c|c|c|c|c|}
\hline Híbrido & Tratamento & IVG & $\begin{array}{l}\text { TMC } \\
\text { (dias }\end{array}$ & & $\begin{array}{l}\mathrm{EP} \\
(\%)\end{array}$ & & IVE & & $\begin{array}{l}\text { TM } \\
\text { (dia }\end{array}$ & \\
\hline \multirow{5}{*}{ H1R } & Controle & $8,07 \mathrm{~A}$ & 2,96 & $\mathrm{AB}$ & 97 & A & 4,01 & A & 6,05 & $\mathrm{~A}$ \\
\hline & fungicida & $8,16 \mathrm{~A}$ & 2,88 & B & 98 & A & 4,07 & A & 6,03 & A \\
\hline & $\begin{array}{l}\text { fungicida }+ \\
\text { inseticida }\end{array}$ & $8,16 \mathrm{~A}$ & 3,07 & A & 97 & A & 3,99 & A & 6,09 & A \\
\hline & $\begin{array}{l}\text { fungicida }+ \\
\text { inseticida }+ \\
\text { nematicida }\end{array}$ & $8,12 \mathrm{~A}$ & 2,99 & $\mathrm{AB}$ & 98 & A & 4,03 & A & 6,08 & A \\
\hline & CV\% & 1,68 & 4,49 & & 3,50 & & 3,84 & & 1,93 & \\
\hline \multirow{5}{*}{$\mathrm{H} 2 \mathrm{R}$} & Controle & $8,05 \mathrm{~A}$ & 3,02 & A & 98 & A & 6,33 & A & 3,95 & A \\
\hline & fungicida & $8,03 \mathrm{~A}$ & 3,03 & A & 98 & A & 6,18 & A & 4,05 & A \\
\hline & $\begin{array}{l}\text { fungicida }+ \\
\text { inseticida }\end{array}$ & $7,93 \mathrm{~A}$ & 2,94 & A & 98 & A & 6,34 & A & 3,98 & A \\
\hline & $\begin{array}{l}\text { fungicida }+ \\
\text { inseticida }+ \\
\text { nematicida } \\
\end{array}$ & $7,99 \mathrm{~A}$ & 3,00 & A & 99 & $\mathrm{~A}$ & 6,00 & A & 4,21 & A \\
\hline & CV\% & 2,87 & 6,81 & & 2,63 & & 4,90 & & 5,05 & \\
\hline \multirow{5}{*}{$\mathrm{H} 3 \mathrm{R}$} & Controle & $8,27 \mathrm{~A}$ & 3,02 & A & 99 & A & 6,02 & A & 4,12 & $\mathrm{AB}$ \\
\hline & fungicida & $8,29 \mathrm{~A}$ & 2,99 & A & 98 & A & 6,00 & A & 4,11 & B \\
\hline & $\begin{array}{l}\text { fungicida }+ \\
\text { inseticida }\end{array}$ & $8,27 \mathrm{~A}$ & 3,02 & A & 98 & A & 5,81 & A & 4,25 & A \\
\hline & $\begin{array}{l}\text { fungicida }+ \\
\text { inseticida }+ \\
\text { nematicida }\end{array}$ & $8,19 \mathrm{~A}$ & 2,97 & A & 100 & A & 6,03 & A & 4,19 & $\mathrm{AB}$ \\
\hline & $\mathrm{CV} \%$ & 0,99 & 2,27 & & 2,40 & & 3,15 & & 2,31 & \\
\hline
\end{tabular}

Médias seguidas pela mesma letra maiúscula na coluna não diferem estatisticamente entre si, para cada híbrido, pelo teste de Tukey $(\alpha=0,05)$. CV\% = coeficiente de variação. 
Tabela 38. Índice de velocidade de germinação (IVG), tempo médio de germinação (TMG), emergência da plântula (EP), índice de velocidade de emergência (IVE) e tempo médio de emergência (TME) nas repetições de 25 sementes de milho, classificadas como chatas (C)

\begin{tabular}{|c|c|c|c|c|c|c|c|c|c|}
\hline Híbrido & Tratamento & IVG & & $\begin{array}{l}\text { TMG } \\
\text { (dias) }\end{array}$ & $\begin{array}{l}\mathrm{EP} \\
(\%) \\
\end{array}$ & & IVE & & $\begin{array}{l}\text { TME } \\
\text { (dias) }\end{array}$ \\
\hline \multirow{5}{*}{$\mathrm{H} 1 \mathrm{C}$} & Controle & 8,27 & A & $3,02 \mathrm{~A}$ & 100 & A & 6,76 & A & 3,76 \\
\hline & fungicida & 8,30 & A & $3,04 \mathrm{~A}$ & 100 & A & 7,04 & A & 3,63 \\
\hline & $\begin{array}{l}\text { fungicida }+ \\
\text { inseticida }\end{array}$ & 8,27 & A & $3,01 \mathrm{~A}$ & 100 & A & 6,87 & A & 3,74 \\
\hline & $\begin{array}{l}\text { fungicida }+ \\
\text { inseticida }+ \\
\text { nematicida }\end{array}$ & 8,28 & A & $3,00 \mathrm{~A}$ & 99 & A & 6,81 & A & 3,72 \\
\hline & CV\% & 0,72 & & 2,29 & 1,17 & & 4,68 & & 4,81 \\
\hline \multirow{5}{*}{$\mathrm{H} 2 \mathrm{C}$} & Controle & 7,65 & A & $2,91 \mathrm{~A}$ & 97 & A & 4,52 & A & 5,43 \\
\hline & fungicida & 7,69 & A & $2,94 \mathrm{~A}$ & 94 & A & 4,42 & A & 5,35 \\
\hline & $\begin{array}{l}\text { fungicida }+ \\
\text { inseticida }\end{array}$ & 7,59 & A & $2,91 \mathrm{~A}$ & 92 & A & 4,28 & A & 5,42 \\
\hline & $\begin{array}{l}\text { fungicida }+ \\
\text { inseticida }+ \\
\text { nematicida }\end{array}$ & 7,39 & $\mathrm{~A}$ & $2,76 \mathrm{~A}$ & 91 & A & 4,19 & A & 5,48 \\
\hline & CV\% & 4,32 & & 16,41 & 7,48 & & 8,61 & & 2,20 \\
\hline \multirow{5}{*}{$\mathrm{H} 3 \mathrm{C}$} & Controle & 8,23 & A & $3,01 \mathrm{~A}$ & 98 & A & 4,90 & A & 5,00 \\
\hline & fungicida & 8,29 & A & $2,96 \mathrm{~A}$ & 100 & A & 5,04 & A & 4,95 \\
\hline & $\begin{array}{l}\text { fungicida }+ \\
\text { inseticida }\end{array}$ & 8,30 & A & $3,03 \mathrm{~A}$ & 99 & A & 5,00 & A & 4,95 \\
\hline & $\begin{array}{l}\text { fungicida }+ \\
\text { inseticida }+ \\
\text { nematicida }\end{array}$ & 8,29 & A & $2,99 \mathrm{~A}$ & 100 & A & 5,04 & $\mathrm{~A}$ & 4,96 \\
\hline & CV\% & 0,77 & & 2,37 & 1,81 & & 2,99 & & 1,67 \\
\hline
\end{tabular}

Médias seguidas pela mesma letra maiúscula na coluna não diferem estatisticamente entre si, para cada híbrido, pelo teste de Tukey $(\alpha=0,05)$. CV\% = coeficiente de variação. 
Os resultados do teste de frio (Tabela 39) não tiveram variação estatística significativa em função dos tratamentos das sementes de milho com produtos químicos, independentemente do híbrido. Os resultados do Controle diferiram estatisticamente dos resultados das sementes tratadas, para os híbridos H2R, H3R, H1C e H3C. Para o híbrido H1R, a quantidade de plântulas emersas do Controle foi estatisticamente inferior à quantidade obtida em função das aplicações dos tratamentos químicos fungicida + inseticida e fungicida + inseticida + nematicida. Para o híbrido H2C, o resultado do Controle foi estatisticamente inferior ao do tratamento fungicida. Esses resultados indicaram que há variação na porcentagem de plântulas emersas do teste de frio, devido à aplicação de produtos químicos nas sementes de milho e essa variação de resultado depende da combinação dos produtos químicos e do híbrido analisado. Há coerência desses resultados, uma vez que, a germinação da semente de milho em solos frios e úmidos é afetada pelo genótipo, pelo tipo de produto utilizado para tratar as sementes e pela forma da semente conforme citado por Barros et al. (1999).

Tabela 39. Plântulas emersas (\%) obtidas no teste de frio das sementes híbridas de milho, 1, 2 e 3, classificadas como redondas $(\mathrm{R})$ e chatas $(\mathrm{C})$

\begin{tabular}{lccccccc}
\hline Tratamento & H1R & H2R & H3R & H1C & H2C & H3C \\
\hline Controle & $90 \mathrm{~B}$ & $21 \mathrm{~B}$ & $56 \mathrm{~B}$ & $70 \mathrm{~B}$ & $81 \mathrm{~B}$ & $86 \mathrm{~B}$ \\
fungicida & $96 \mathrm{AB}$ & $98 \mathrm{~A}$ & $96 \mathrm{~A}$ & $93 \mathrm{~A}$ & $93 \mathrm{~A}$ & $99 \mathrm{~A}$ \\
fungicida + inseticida & $98 \mathrm{~A}$ & $95 \mathrm{~A}$ & $96 \mathrm{~A}$ & $93 \mathrm{~A}$ & $90 \mathrm{AB}$ & $100 \mathrm{~A}$ \\
$\begin{array}{l}\text { fungicida + inseticida + } \\
\text { nematicida }\end{array}$ & $98 \mathrm{~A}$ & $94 \mathrm{~A}$ & $95 \mathrm{~A}$ & $93 \mathrm{~A}$ & $88 \mathrm{AB}$ & $99 \mathrm{~A}$ \\
\hline \begin{tabular}{l} 
CV $(\%)$ \\
\hline
\end{tabular} & 3,75 & 7,76 & 6,02 & 4,02 & 5,36 & 2,43 \\
\hline
\end{tabular}

Médias seguidas pela mesma letra maiúscula na coluna não diferem estatisticamente entre si, para cada híbrido e forma das sementes, pelo teste de Tukey $(\alpha=0,05) . \mathrm{CV}=$ coeficiente de variação. 


\section{CONCLUSÕES}

Os resultados do teste de germinação das sementes de milho foram analisados, estatisticamente e utilizando as Tabelas de Tolerância das Regras para Análise de Sementes, e é possível verificar que o tratamento industrial das sementes não interfere nos resultados da avaliação do teste de germinação, conforme proposto nas atuais Regras para Análise de Sementes.

No teste de germinação, é possível avaliar a germinação das sementes de milho no $3^{0}$ dia após a instalação do teste, para antecipar a obtenção dos resultados.

A colocação de 25 sementes de milho no substrato papel (RP) favorece a avaliação do desenvolvimento da plântula no teste de germinação, em comparação à utilização de 50 sementes. 


\section{REFERÊNCIAS}

ABIMILHO. Oferta e demanda de milho no Brasil. São Paulo, 2016.

ABRASEM. Anuário 2015. Associação Brasileira de Sementes e Mudas. Brasília, 2015. $110 \mathrm{p}$.

AGROFIT. Sistema de Agrotóxicos Fitossanitários. Disponível em: <http://agrofit.agri cultura.gov.br/agrofit_cons/principal_agrofit_cons>. Acesso em: 27 maio 2017.

AGUILERA, L. A.; CARON, B. O.; CELLA, W. L.; LERSCH JUNIOR, I. Qualidade fisiológica de sementes de milho em função da forma e do tratamento químico das sementes. Ciência Rural, Santa Maria, v. 30, n. 2, p. 211-215, 2000.

AKCELRUD, L. Fundamentos da ciência dos polímeros. Barueri: Manole, 2007.

ARAÚJO, F. G. Perigo tratado. Pelotas: Grupo Cultivar, 2016. Disponível em: <http://www.grupocultivar.com.br/artigos>. Acesso em: 14 out. 2016.

BARROS, A. S. R.; DIAS, M. C. L. L.; CICERO, S. M.; KRZYZANOWSKI, F. C. Teste de frio. In: KRZYZANOWSKI, F. C.; VIEIRA, R. D.; FRANÇA NETO, J. B. Vigor de sementes conceitos e testes. Abrates, 1999.

BRASIL. Ministério da Agricultura, Pecuária e Abastecimento. Regras para Análise de Sementes. Brasília: Mapa/ACS, 2009. 399p.

BUlEGON, L. G.; CASTAGNARA D. D.; TSUTSUMI, C. Y.; ERIG, M. C.; ZOZ, T. Germinação e emergência de sementes de diferentes tamanhos submetidas à tratamentos químicos. Revista de Agricultura Neotropical, Cassilândia, v. 2, n. 2, p. 86-94, abr./jun. 2015 .

CONAB. Acompanhamento da safra brasileira de grãos: décimo segundo levantamento. Brasília: CONAB, v.3, n.12, 2016. 182p. 
COSTA, R. V.; CASELA, C. R.; COTA, L. V. Cultivo do milho: doenças. Sete Lagoas: Embrapa Milho e Sorgo, 2009. Disponível em: <http://www.cnpms.embrapa.br/publicacoes/ milho_5_ed/doencas.htm>.Acesso em: 10 out. 2016.

CRUZ, I. Manejo de pragas da cultura do milho. In: CRUZ, J. C.; KARAM, D.; MONTEIRO, M. A. R.; MAGAlHAES, P. C. (Ed.). A cultura do milho. Sete Lagoas: Embrapa Milho e Sorgo, 2008. cap. 12, p. 303-362.

CRUZ, J. C.; PEREIRA FILHO, I. A.; ALVARENGA, R. C. Preparo do solo e plantio. In: GAlvÃO, J. C. C.; BORÉM, A.; PIMENTEL, M. A. (Ed.). Milho: do plantio à colheita. Viçosa: UFV, 2015. p.77-107.

DHINGRA, O. D.; MUCHOVEJ, J. J.; CRUZ FILHO, J. Tratamento de sementes. Viçosa: UFV, 1980. 121p.

EDMOND, J. B.; DRAPALA, W. J. The effects of temperature, sand and soil, and acetone on germination of okra seed. Proceedings of the American Society Horticutural Science, Alexandria, n. 71, p. 428-434, 1958.

FANCElli, A. L.; DOURADO NETO, D. Produção de milho. 2 ed. Piracicaba: Os Autores, 2004. 360p.

FRAC. Modo de ação de fungicidas. Disponível em: < http://www.frac-br.org/modo-deacao>. Acesso em: 16 out 2016.

GAZZONI, D. L. (Ed.). Tiametoxam: uma revolução na agricultura brasileira. São Paulo: Vozes, 2008.

IBGE. Levantamento sistemático da produção agrícola: pesquisa mensal de previsão e acompanhamento das safras agrícolas no ano civil. Rio de Janeiro: IBGE, v.29, 2016.

IMEA. Custo de produção de milho: safra 2016/2017. Cuiabá: IMEA, 2016. 7p. 
IRAC. Modo de ação de inseticidas e acaricidas. Disponível em: <http://www.iracbr.org/modo-de-ao-de-inseticidas-e-acaricidas>. Acesso em: 16 out. 2016.

ISTA. Proceedings of International Seed Testing Association, v.28, n.3, 1963.

MACHADO, J. C.; WAQUIL, J. M.; SANTOS, J. P.; REICHENBACH, J. W. Tratamento de sementes no controle de fitopatógenos e pragas. Informe Agropecuário, Belo Horizonte, v.27, n.232, p.76-87, 2006.

MAGALHÃES, M. F. Desempenho das sementes de milho tratadas com inseticida, fungicida e nematicida durante o armazenamento. Dissertação (Mestrado em Ciências). Universidade Federal de Pelotas. Pelotas, 2013. 43p.

MAGUIRE, J. D. Speed of germination-aid in selection and evaluation for seedling emergence and vigor. Crop Science, Madison, v. 2, n. 1, jan./feb. 1962.

MAPA. Ministério da Agricultura Pecuária e Abastecimento. Diário Oficial da União. Instrução Normativa № ${ }^{\mathrm{o}}$ 45, de 17 de Setembro de 2013.

MELO, L. F.; FAGIOLI, M.; SUSSTRUNK, T. F. Tratamento de sementes de milho com fipronil e thiamethoxam e sua influência fisiológica nas sementes. Agropecuária Técnica, v. 31, n. 2, 2010.

MENTEN, J. O. M.; LIMA, L. C. S. F.; FRARE, V. C.; RABALHO, A. A. Evolução dos produtos fitossanitários para tratamento de sementes no Brasil. In: ZAMBOLIM, L. (Ed.). Sementes: qualidade fitossanitária. Viçosa: UFV, 2005. p.333-374.

MENTEN, J. O.; MORAES, M. H. D. Tratamento de sementes: histórico, tipos, características e benefícios. Informativo Abrates, Londrina, v. 20, n.3, 2010.

MENTEN, J. O. M. Tratamento industrial de sementes: situação atual e perspectivas. Conselho Científico para Agricultura Sustentável. 2016. 
NUNES, J. C. S. Tratamento de sementes de soja como um processo industrial no Brasil. Seed News, Pelotas, n.1, jan./fev. 2016.

PARISI, J. J. D.; MEDINA P. F. Tratamento de Sementes. Campinas: IAC, 2013. 7p.

PESKE, S. T.; MENEGHELLO, G. E. Limites, tolerâncias e padrões. Seed news, Pelotas, n.5, set./out. 2013 .

PESKE, C. T.; VILlELA, F. A.; MENEGHELlO, G. E. Promovendo os benefícios da semente de alta qualidade. Seed news, Pelotas, n.2, mar./abr. 2016.

USDA. Grain: world markets and trade. United States Department of Agriculture. Washington, 2016. 58p.

VILLELA, F. A.; MERTZ, L. M.; BUZZERIO, N. F.; MENEZES, N. L. Adequação do teste de germinação para sementes de milho submetidas ao tratamento químico. Informativo Abrates, Londrina, v. 23, n.2, 2013. 